NBER WORKING PAPER SERIES

\title{
STOCK OPTIONS FOR UNDIVERSIFIED EXECUTIVES
}

\author{
Brian J. Hall \\ Kevin J. Murphy \\ Working Paper 8052 \\ http://www.nber.org/papers/w8052
NATIONAL BUREAU OF ECONOMIC RESEARCH 1050 Massachusetts Avenue
Cambridge, MA 02138 \\ December 2000
}

We are grateful for research support from the Division of Research at Harvard Business School (Hall) and USC's Marshall School (Murphy). We thank Rajesh Aggarwal, George Baker, Bengt Holmstrom, Rick Lambert, Tom Knox, Ed Lazear, and Jeremy Stein, Robert Verrecchia for helpful comments, and Sahir Islam, Mike Cho and especially Tom Knox for very helpful research assistance. The views expressed in this paper are those of the authors and not necessarily those of the National Bureau of Economic Research.

(C) 2000 by Brian J. Hall and Kevin J. Murphy. All rights reserved. Short sections of text, not to exceed two paragraphs, may be quoted without explicit permission provided that full credit, including $(\mathrm{C}$ notice, is given to the source. 
Stock Options for Undiversified Executives

Brian J. Hall and Kevin J. Murphy

NBER Working Paper No. 8052

December 2000

JEL No. J33, J44, G13, G32, M12

\section{$\underline{\text { ABSTRACT }}$}

We employ a certainty-equivalence framework to analyze the cost and value of, and pay/performance incentives provided by, non-tradable options held by undiversified, risk-averse executives. We derive "Executive Value" lines, the risk-adjusted analogues to Black-Scholes lines, and distinguish between "executive value" and "company cost." We demonstrate that the divergence between the value and cost of options explains, or provides insight into, virtually every major issue regarding stock option practice including: executive views about Black-Scholes measures of options; tradeoffs between options, stock and cash; exercise price policies; connections between the pay-setting process and exercise price policies; institutional investor views regarding options and restricted stock; option repricings; early exercise policies and decisions; and the length of vesting periods. It also leads to reinterpretations of both cross-sectional facts and longitudinal trends in the level of executive compensation.

Brian J. Hall

Harvard Business School

Baker West 185

Boston, MA 02163

and NBER

bhall@hbs.edu
Kevin J. Murphy

USC

Marshall School of Business

Finance and Business Economics

Los Angeles, CA 90089

kjmurphy@usc.edu 


\section{Stock Options for Undiversified Executives}

by

Brian J. Hall and Kevin J. Murphy

\section{Introduction}

Stock options, which give the recipient the right to buy a share of stock at a prespecified exercise price for a pre-specified term, have emerged as the single largest component of compensation for US executives (Hall and Liebman, 1998; Murphy, 1999). In fiscal 1998, 97\% of S\&P 500 companies granted options to their top executives, compared to only $82 \%$ in 1992 . Moreover, the grant-date value of stock options accounted for $40 \%$ of total pay for S\&P 500 CEOs in 1998, up from only $25 \%$ of total pay in $1992 .{ }^{\text {. Stock-options }}$ have become increasingly important for rank-and-file workers as well: $45 \%$ of US companies awarded options to their exempt salaried employees in 1998, while $12 \%$ and $10 \%$ awarded options to their non-exempt and hourly employees, respectively.

In addition to conveying compensation, executive stock options provide a direct link between executive wealth and company stock-price performance, and therefore mitigate agency problems between shareholders and managers (Jensen and Meckling, 1976). Indeed, as documented by Jensen and Murphy (1990) and Hall and Liebman (1998), virtually all of the sensitivity of pay to corporate performance for the typical CEO is attributable to his or her holdings of company stock and stock options, and not to accounting-based bonuses or year-to-year changes in other components of compensation.

Given the emerging dominance of stock options in the provision of both compensation and incentives, it is important to find ways to measure both the value and the incentives provided by executive stock options. Virtually all research in the area-including papers written by both authors and all the "facts" noted in the previous two paragraphs - relies on

1 Data extracted from Compustat's ExecuComp database, using grant-date option values based on ExecuComp's Black-Scholes' calculations.

2 Prevalence data are based on the American Compensation Association's 1997-1998 Salary Budget Survey, and include survey results from 735 publicly traded corporations. 
option pricing formulas such as Black-Scholes (1973) to evaluate executive options. But executive stock options differ in critical ways from the options priced in the valuation formulas. In particular, while option-pricing theory assumes that options are freely tradable and that option holders can hedge the risk of options by short-selling stock, executive options are non-tradable and held by risk-averse, undiversified executives who cannot easily hedge. While researchers and practitioners have routinely noted the shortcomings of using standard option formulas to value executive options, there have been few attempts to "correct" for the non-tradability of executive options, or to explore the implications of such a correction.

In this paper, we analyze the cost and value of, and pay/performance incentives provided by, non-tradable stock options held by risk-averse, undiversified executives. We show that the company's cost of granting options typically exceeds the value of the options to executive-recipients, and demonstrate that this simple result has implications for virtually every issue related to executive stock options - from option design to executive behavior to stylized facts regarding compensation levels. Many researchers have documented that executive pay policy is influenced by tax, accounting, political, and agency-theoretic considerations. While acknowledging the roles of these considerations, we show that simply recognizing the divergence between cost and value explains, or provides intuition about:

1. Why executives often argue that Black-Scholes values are too high,

2. Why executives typically demand large premiums to exchange options for cash, suggesting that options are an expensive way to convey pay,

3. Why virtually all options are granted at-the-money,

4. Why premium options, which have strong advocates because they create a "tougher" performance standard for executives, are rarely granted in practice,

5. Why restricted stock is preferable to options under certain conditions regarding the pay-setting process for executives,

3 For example, every empirical paper in the recent JFE special issue on stock options (a Symposium on Executive Stock Options, Journal of Financial Economics, July 2000) uses Black-Scholes to value executive stock options.

4 Exceptions include Lambert, Larcker, and Verrecchia (1991), Kulatilaka and Marcus (1994), Rubenstein (1995), Carpenter (1998), Murphy (1999), DeTemple and Sundaresan (1999), Meulbroek (2000) and Hall and Murphy (2000).

5 The loss associated with this value:cost differential, of course, must be weighed against the incentive benefits of options in order to determine their net benefits as a compensation instrument. See Hemmer, Kim and Verrecchia (2000) for analysis of the conditions under which options represent an optimal incentive contract. 
6. Why institutional investors (and other governance activists) nevertheless criticize restricted stock,

7. Why companies often re-set the exercise price on underwater options, and how cost-neutral re-settings can be beneficial to shareholders and executives,

8. Why executives often exercise stock options well before expiration (even for non-dividend paying stocks), forfeiting substantial option value,

9. Why companies allow executives to exercise options prior to expiration, and why this policy is generally advantageous to both executives and shareholders,

10. Why options are often exercised on the day they become vested,

11. Why short vesting periods of two to four years (which have modest effects on executive value and company cost) are common, and why long vesting periods are almost never observed in practice,

12. Why CEO pay levels have increased substantially in recent years (while riskadjusted increases have been relatively modest),

13. Why CEO pay levels vary across industries (the riskiness of the pay package explains, for example, a large part of the observed differences).

The paper proceeds as follows. Section 2 develops our framework for both valuing stock options and measuring the incentives created by such options. We distinguish between the cost to the company and the value to the executive-recipient. Ignoring (for the moment) complications related to early exercise, potential forfeiture, and executive inside information, option-pricing methodologies such as Black-Scholes are appropriate for measuring the amount outside investors would pay for an option, and therefore provide an estimate of the company's cost of granting an option. We estimate the value of non-tradable options to an undiversified risk-averse executive using the "certainty equivalence" approach, following Lambert, Larcker, and Verrecchia (1991), and show that option-pricing formulas such as Black-Scholes generally overstate the value an executive places on a non-tradable option.

In addition to introducing our framework, Section 2 explores several implications of our comparison of the cost and value of executive stock options. We derive "Executive Value" lines, the analogues to Black-Scholes ("company cost") lines. This analysis supports frequent claims by executives that Black-Scholes values are "too high," and also explains why executives often demand large premiums to accept options in lieu of cash payments. We show that these premiums should depend on whether the option is in-the-money or out-of-

Following Lambert, Larcker and Verrecchia (1991), other researchers have also noted or analyzed the difference between executive value and company cost. See Abowd and Kaplan (1999) and Meulbroek (2000) for examples. 
the-money, which in turn depends on the probability that the option will expire unexercised. Finally, our results also have implications for academic research that adds options values to other risky components of pay to establish "total compensation." At best, this aggregate calculation is a measure of the company's cost of the compensation package, and not an estimate of the executive's value of the compensation package. We show that, while the reported level of total compensation for S\&P 500 executives has risen dramatically from 1992 to 1998, the growth in "risk-adjusted pay" has been relatively modest, suggesting that executive value has increased far less than company cost during the period.

Section 3 analyzes the pay/performance incentives created by non-tradable executive options. We define incentives as the derivative of the executive's value with respect to the stock price, and consider the incentive effects of setting the exercise price above the grantdate market price (premium options) or below the grant-date price (discount options), and repricing options following declines in stock prices. We solve for exercise prices that maximize incentives holding constant the company's net cost of granting options, where the net cost depends on whether the grant is an "add-on" to existing pay or granted with simultaneous reductions in other forms of compensation. We show that incentives are maximized at exercise prices at or near the grant-date market price when the grant is an addon, but incentives are maximized at exercise prices close to zero (i.e., restricted stock) when the executive is "charged" for the options through reduced cash compensation. Our results suggest that common prescriptions in the business press, such as setting higher performance hurdles by issuing premium options and refraining from repricings following stock price declines - are not generally in the interest of shareholders, or at least have serious drawbacks.

Section 4 relaxes our maintained assumption that options are held for their full term, and analyzes the timing of exercise decisions by risk-averse executives. Several researchers have documented that executive (and employee) options are exercised relatively early in their term, even when the underlying stock pays no dividends. Such behavior is entirely consistent with our framework: risk-averse executives will exercise early following price run-ups to "lock in" a gain. More importantly, we demonstrate that allowing early exercise increases option "efficiency" by narrowing the value:cost divergence of option grants. Early exercise simultaneously increases the value to the executive-recipient (risk-averse executives value the potential opportunity to lock-in gains) while also reducing the company's cost of the option (precisely because the executive will exercise "too early" from an outside

7 See, for example, Huddart and Lang (1996). 
investor's standpoint). Our framework also enables us to analyze vesting policies and helps explain why vesting periods are typically in the two to four-year range, and almost never longer.

Finally, our framework offers some general implications for the design of employee bonus plans. Section 5 summarizes and generalizes these findings.

\section{Option Values for Undiversified Executives}

Central to modern option theory is the idea that option holders can fully hedge the risk associated with holding options by short-selling the underlying stock or taking similar actions that achieve the same purpose. Black and Scholes (1973) and Merton (1973) demonstrated that, since investors can hedge, options can be valued as if investors were risk neutral and all assets appreciate at the risk-free rate. Under these assumptions, the value of options can be estimated by computing the expected value of the option upon exercise assuming that the expected return on the stock is equal to the risk-free rate, and then discounting the expected value to the grant date using the risk-free rate. This risk-neutrality assumption is central to all option pricing models and methodologies, including the BlackScholes model (as amended by Merton to account for dividends), binomial models, arbitrage pricing models and Monte Carlo methodologies.

Compensation consultants, practitioners, and academic researchers have routinely used Black-Scholes or similar methodologies to value executive stock options. However, while the assumptions underlying option-pricing methodologies reasonably describe the situation faced by sophisticated outside investors holding freely traded options, they do not describe the situation faced by executives (and other employees) holding options on their own company's stock. In contrast to outside investors, company executives cannot trade or sell their options, and are also forbidden from hedging the risks by short-selling company stock; such actions would obviously defeat a primary purpose of the option grants, which is to align the financial interests of the managers with those of the shareholders. In addition, while outside investors tend to be well-diversified (holding small amounts of stock in a large number of companies), company executives are inherently undiversified, with their physical

8 See Hull (1997) and Merton (1997) for a comprehensive treatment of these issues.

9 Although executives cannot explicitly short-sell company stock they may engage in related transactions (such as zero-cost collars) that reduce their risk. Existing evidence suggests that such transactions are observed but are not widespread (Bettis, Bizjak, and Lemmon, 1999). 
as well as human capital invested disproportionately in their company. ${ }^{4}$ These substantive violations of the underlying assumptions suggest that traditional methodologies are not appropriate in determining the value of executive stock options.

When defining the "value" of executive stock options, it is critical to distinguish between two fundamentally distinct option valuation concepts: the economic cost to the company, and the economic value to the executive-recipient. The economic or opportunity cost of granting an option is the amount the company could have received if it were to sell the option to an outside investor rather than giving it to the executive. Ignoring for the moment complications related to potential forfeiture, early exercise, and executive inside information, traditional valuation formulas provide an estimate of how much outside investors would pay for an option, and therefore represent an estimate of the company's cost of granting an option. However, traditional valuation methodologies do not measure the value of a non-tradable option to an undiversified, risk-averse executive.

We estimate the value of a non-tradable option to an undiversified risk-averse executive as the amount of riskless cash compensation the executive would exchange for the option, using a "certainty equivalence" approach similar to that adopted by Lambert, Larcker, and Verrecchia (1991). In particular, we suppose that an executive has non-firmrelated wealth of $w$, holds $s$ shares of company stock, and is granted $n$ options to buy $n$ shares of stock at exercise price $X$ in $T$ years. Assuming that $w$ is invested at the risk-free rate, $r_{f}$, and that the realized stock price at $T$ is $P_{T}$, the executive's wealth at time $T$ is given by

$$
W_{T} \equiv w\left(1+r_{f}\right)^{T}+s P_{T}+n \bullet \max \left(0, P_{T}-X\right)
$$

If, instead of the option, he were awarded $V$ in cash that he invested at the risk-free rate, his wealth at time $T$ would be:

$$
W_{T}^{V} \equiv(w+V)\left(1+r_{f}\right)^{T}+s P_{T}
$$

We assume the executive's utility over wealth is $U(W)$, and define the executive's value of $n$ options as the certainty equivalent $V$ that equates expected utilities (1) and (2):

$$
\int U\left(W_{T}^{V}\right) f\left(P_{T}\right) d P_{T} \equiv \int U\left(W_{T}\right) f\left(P_{T}\right) d P_{T}
$$

10 Indeed, in addition to being "forced" not to trade or hedge their options, executives are routinely required (through ownership guidelines imposed by the board) or pressured (by informal board requirements or through the desire to signal to markets) to hold more company stock than dictated from an optimalportfolio standpoint. 
Solving (3) numerically requires assumptions about the form of the utility function, $U(W)$, and the distribution of future stock prices, $f\left(P_{T}\right)$. We assume that the executive has constant relative risk aversion $\rho$, so that $U(W) \equiv \ln (W)$ when $\rho=1$, and $U(W) \equiv \frac{1}{1-\rho} W^{1-\rho}$ when $\rho \neq 1$. We adopt the Capital Asset Pricing Model (CAPM) and assume that the distribution of stock prices in $T$ years is lognormal with volatility $\sigma$ and expected value equal to $\left(r_{f}+\beta\left(r_{m^{-}}\right.\right.$ $\left.\left.r_{f}\right)-\sigma^{2} / 2\right) T$, where $\beta$ is the firm's systematic risk and $r_{m}$ is the return on the market portfolio. ${ }^{4 n l e s s}$ otherwise noted, the figures and numerical calculations in this article are derived assuming no dividends, $\sigma=.30$ (the median volatility for S\&P 500 firms), $\beta=1$ (the market average beta, by definition), $r_{f}=6 \%$, and an equity premium of $r_{m}-r_{f}=6.5 \%$. The qualitative results in this paper are not sensitive to reasonable changes in these parameters.

\subsection{Executive Value Lines}

Figure 1 illustrates our methodology by showing how the value of a ten-year nontradable stock option with an exercise price of $\$ 30$ varies with changes in stock prices. The "intrinsic value" is defined as the (positive) spread between the market price and exercise price, and the Black-Scholes value, $C(P)$, approximates the company's cost of granting an option. These two lines, showing option payouts and values, are of course standard in option analyses. What is new in Figure 1 are the "executive value" lines, which plot the certaintyequivalent values as a function of stock prices. The figure depicts the per-share values of non-tradable options to undiversified executives, assuming that executives have $\$ 5$ million in initial wealth split between company stock and safe cash, and assuming that executives receive a grant of options to purchase one share of stock at an exercise price of $\$ 30$. Four executive-value lines are drawn, for different pairs of risk aversion and diversification, representing executives with relative risk aversion of $\rho=2$ or $\rho=3$ and holding either $50 \%$ or $67 \%$ of their wealth in company stock.

Under traditional valuation methodologies, option values depend on six factors: the exercise price, stock price, dividend yield, stock-return volatility, risk-free rate, and the time until expiration. Our numerical analysis of equation (3) shows that the certainty-equivalent value (that is, the value of a non-tradable option to an executive recipient) depends on these six parameters, but also depends on the executive's risk-aversion, initial wealth, and

11 For tractability, we assume that the distribution of future stock prices is the same whether the executive receives options or cash. If the grant provides incentives that shift the distribution, and if the shift is not already incorporated into stock prices as of the grant date, we will underestimate both the cost and value of the option. Since most of our results hinge on the difference between (rather than the levels of) cost and value, this assumption does not affect our main qualitative results. 
diversification. Figure 1 illustrates these new comparative static results. For example, executive values are strictly decreasing in risk-aversion: the executive value lines for executives with relative risk aversion of $\rho=3$ lie strictly below those for executives with $\rho=2$. In addition, executives with large holdings of company stock (relative to their wealth) place lower values on options: the executive value lines for executives holding $67 \%$ of their initial wealth in company stock (rather than safe cash) lie strictly below those for executives holding $50 \%$ of their wealth in stock.

The executive value lines in Figure 1 lie below the Black-Scholes line, $V(P)<C(P)$, indicating that risk-averse executives value non-tradable options at significantly less than their cost to the company. ${ }^{2}$ Table 1 shows the ratio of the executive's value to the company's cost, for a variety of stock prices and combinations of risk-aversion and diversification. The table shows, for example, that an option granted at-the-money is worth $63.5 \%$ of its Black-Scholes cost (of $\$ 16.55$ ) to an executive with $\rho=2$ and $50 \%$ of his wealth in company stock, but only worth $21.1 \%$ of its cost for an executive with $\rho=3$ and $67 \%$ of his wealth in stock. The table also shows that the value:cost ratio increases with stock prices (holding the exercise price fixed at \$30). For example, for an executive with $\rho=2$ and $67 \%$ of his wealth in company stock, an option with a $\$ 30$ exercise price is worth $55 \%$ of its BlackScholes cost (of $\$ 44.40$ ) when the stock price is $\$ 60$, but is only worth about $32 \%$ of its cost (of $\$ 4.95$ ) when the stock price is $\$ 15$.

In addition to reporting value:cost ratios, Table 1 also reports the probabilities that the ten-year option will be in-the-money at the end of its term. ${ }^{4}$ For example, an option granted at $\$ 30$ when the stock price is $\$ 60$ will expire in-the-money with probability $93 \%$, while the same option granted when the stock price is only $\$ 5$ will expire in-the-money with probability $13 \%$. These probabilities provide useful intuition in explaining why the value:cost ratios increase with stock prices: value:cost ratios are higher when the payout probability is higher. Black-Scholes option values are substantially affected by small

The executive-value line can actually lie above the Black-Scholes line if executives are sufficiently diversified and have sufficiently low risk aversion, since stock returns include a risk premium, $\beta\left(r_{m}-r_{f}\right)$, characterizing the risk-preferences of the marginal investor and not those of a well-diversified executive. (Our results here differ from Lambert, Larcker, and Verrecchia (1991), who ignore the risk premium and conclude that the Black-Scholes value is the upper-bound value for undiversified executives.) We ignore cases where executive value is higher than the Black-Scholes cost since it is not an equilibrium outcome: companies would give more options (and/or executives would purchase more stock) until the executive value is driven below the Black-Scholes cost.

13 The probability that the market price at expiration, $P_{T}$, exceeds the exercise price, $X$, is calculated under the standard CAPM assumption that $\operatorname{Ln}\left(P_{T} / P_{0}\right)$ is normally distributed with mean $\mu=\operatorname{Ln}\left(r_{f}+\beta\left(r_{m}-r_{f}\right)-\sigma^{2} / 2\right) T$ and variance $\sigma^{2} T$. 
probabilities of large outcomes, while risk-averse individuals naturally discount small probabilities of large outcomes.

This section began by noting that Black-Scholes or similar methodologies are widely used in valuing executive stock options. Our analysis demonstrates that, at best, the traditional approach yields an estimate of the company's cost of granting an option, but will generally overstate the value of the option to the executive recipient by a substantial margin. This seemingly obvious, but often overlooked, result has important implications for understanding executive stock option plans and, more generally executive compensation practices.

\subsection{Implications}

\subsubsection{Black-Scholes values are too high}

Under current accounting rules, the value of stock options granted to executives and other employees is not considered compensation expense and is not deducted from corporate earnings upon grant. In 1993, the Financial Accounting Standards Board (FASB) proposed rule changes that would force companies to deduct the grant-date value of options from corporate earnings. Although FASB ultimately adopted enhanced footnote disclosure rather than explicit accounting charges, the proposal created a storm of criticism among business executives, high-tech companies, accountants, compensation consultants, the Secretary of the Treasury, and shareholder groups. ${ }^{44}$ The chief concern offered by the business community, especially the Business Roundtable and Silicon Valley, was that traditional pricing methodologies such as Black-Scholes substantially overstate the value of executive stock options.

Our analysis of the cost and value of non-tradable options lends support to the claim that the Black-Scholes formula overstates the value of options from the executive's perspective. As reported in Table 1, an executive with risk aversion $\rho=3$ holding $67 \%$ of his

14 See, for example, Lee Berton, "Business chiefs try to derail proposal on stock options," Wall Street Journal (February 5, 1992); Christi Harlan and Lee Berton, "Accounting Firms, Investors Criticize Proposal on Executives' Stock Options," Wall Street Journal (February 19, 1992); "Bensten Opposes FASB On Reporting Stock Options," Wall Street Journal (April 7, 1993); "Clinton Enters Debate Over How Companies Reckon Stock Options," Wall Street Journal (December 23, 1993); Lee Berton, "Accounting Rule-Making Board's Proposal Draws Fire," Wall Street Journal (January 5, 1994); Christi Harlan, "High Anxiety: Accounting Proposal Stirs Unusual Uproar In Executive Suites," Wall Street Journal (March 7, 1994). 
wealth in stock will only value an at-the-money option at about one-fifth of its Black-Scholes value. However, while the executive objections are understandable, they are misplaced: for financial accounting purposes, what should matter is the company's cost of granting an option — not the value of the option to the executive recipient — and Black-Scholes provides a reasonable estimate of the company's cost.

Our assertion that Black-Scholes is appropriate in measuring the company's cost of stock options merits a couple of caveats. First, executive stock options typically "vest" over three to five years following grant, and are subject to forfeiture if the executive ceases employment prior to vesting. Although estimating the impact of forfeiture requires information on departure probabilities, the potential forfeiture clearly lowers both the value and cost of executive options. Second, while executive options are typically exercisable upon vesting, Black-Scholes valuations are appropriate only for options held until expiration. As discussed at length below in Section 4, early exercise provisions can simultaneously lower the company's cost of granting the option, while raising the value to the executive recipient.

Third, executives may posses private information about company prospects. This will certainly affect (either positively or negatively) both the opportunity cost and the perceived value of the option. While admitting its potential importance, we ignore the effects of inside information in this paper. Finally, the "net cost" of granting an option is clearly less if the executive receives the option in lieu of lower cash compensation, or if (as if hopefully the case) the option improves managerial incentives. We consider both of these factors "benefits" of options that must be weighed against their cost in determining optimal option granting practices.

\subsubsection{Exchanges of Cash for Stock-Based Compensation}

In recent years, many companies have shifted the pay "mix" away from base salary and towards stock-based compensation. In most cases, these shifts have been subtle and gradual, with little or no formal discussion or disclosure. A significant number of companies, however, have conducted explicit exchanges of cash for stock-based compensation. Although the exchanges have taken a variety of forms, most involve exchanging cash bonuses or current or future increases in base salaries for restricted stock or options.

15 Companies recently completing such exchanges include Arkla, Avon, Baxter, Black \& Decker, Clorox, EKCO, General Mills, Harnischfeger, International Multifoods, Mead, Merck, PacifiCorp, Panhandle Eastern, Santa Fe Pacific, Sun Company, Teledyne, Toro, Triarc, Union Carbide, United Airlines, and USAir. 
Executives participating in exchanges typically receive a "risk premium" for accepting stockbased pay rather than cash. For example, consider EKCO's exchange program as described in its 1995 proxy statement.

The 1995 Incentive Plan provides the participants with the option to have all or a portion of any bonus and any increase in base compensation paid either (i) in cash, (ii) deferred until a specified date or time with interest to be paid by the Company at a rate agreed to by the Committee, (iii) in shares of restricted stock valued at $130 \%$ of the foregone cash payment based upon the market price of such Common Stock on the last trading day of the year preceding the year to which the payment relates, or (iv) stock options valued at $250 \%$ of the foregone cash payment according to the Black-Scholes method of valuation and calculated as of the last trading day of the year preceding the year to which the payment relates.

As our analysis above suggests, risk premiums such as that offered by EKCO are necessary because risk-averse and undiversified executives will be willing to exchange cash for stock or options only if the dollar value of the stock or options received substantially exceed the dollar value of cash foregone. Figure 2 plots indifference curves showing the amount of stock-based pay required to offset a loss of $\$ 300,000$ in cash compensation, while keeping the executive at the same expected utility. That figure shows, for example, that an executive with $\rho=2$ and $50 \%$ of his wealth in company stock will be indifferent between receiving $\$ 300,000$ in cash (representing $6 \%$ of his initial wealth), $\$ 375,000$ in restricted stock (representing a 25\% risk premium), $\$ 500,000$ in options issued at fair market value (FMV) (a 67\% risk premium), or $\$ 750,000$ in options with an exercise price double the current market price (a 150\% risk premium). As evident from the graph, the required risk premiums increase substantially for more risk-averse and less diversified executives, and are especially large for options issued out-of-the-money with lower payout probabilities.

Proponents of broad-based stock option plans extending to all company employees often argue that options are an efficient way to pay employees because there is no accounting charge and no company cash outlay upon grant. Figure 2 illustrates that options are, in fact, an unusually expensive and therefore inefficient way to convey compensation to executives and employees: the economic cost to shareholders of granting options often far exceeds the value that employee-recipients place on the option. Stock options are efficient only when the incentive benefits of the options (including both pay-to-performance and retention incentives) exceed their "inefficiency cost." In many cases, this suggests focusing (or even limiting) grants to senior executives and other key employees who have a reasonably direct 
impact on company stock prices. And although some broad-based plans may well be justified on the basis of (hard-to-model) beneficial effects on employee morale and company culture, we suspect that many of these plans are driven by the favorable but ultimately irrelevant accounting treatment of options-not a careful weighing of the benefits of stock options against their full economic costs.

Finally, although our analysis suggests a significant value:cost differential for options, our estimated magnitudes are, in general, consistent with other evidence. For example, Meulbroek (2000) measures the value:cost "inefficiency" of options using a completely different (non-utility-based) approach. Her method enables her to make precise estimates of what she calls the "deadweight cost" of option grants without knowledge of the specific utility function or wealth holdings of executives. Her approach produces a lower bound estimate of the value:cost inefficiency since her goal is to isolate the deadweight cost owing to sub-optimal diversification, while abstracting from any additional deadweight cost from the specific structure of the compensation contract. ${ }^{47}$ Applying her methodology to Internet companies, she finds a very substantial (lower bound of) value:cost inefficiency of more than 50 percent.

\subsubsection{Risk-adjusted pay}

Figure 3 illustrates the relative importance of the various components of compensation for CEOs in S\&P 500 Industrials (that is, the S\&P 500 companies excluding utilities and finance firms), and also documents how the level and composition of pay has varied from 1992-1998. The bar height depicts median total compensation in CPI-adjusted 1998-constant dollars, including salaries, realized bonuses, stock-based compensation, and other pay. Stock-based pay includes the grant-date cost of stock options (valued using the BlackScholes formula), restricted stock grants (valued at year-end stock prices), and performance shares (valued as the target grant multiplied by the year-end stock price). Pay component

16 Oyer (2000) argues that broad-based option programs can help keep low-level workers near their participation constraints when worker reservation wages vary with firm performance. Himmelberg and Hubbard (2000) present a similar argument based on an assumption that marginal productivity varies with market-wide stock market shocks. Underlying both arguments is the idea that compensation plans based on company performance can affect "retention incentives" as well as effort incentives. Our results suggest that such programs may be inefficient relative to less risky deferred compensation plans in providing retention incentives to risk-averse undiversified workers.

17 We require a utility-based approach (which produces estimates of the combined value:cost inefficiency from non-diversification and the sub-optimality of the specific compensation contract), since the focus of our paper is on analysis of the structure of the compensation package. 
percentages are derived from Compustat's ExecuComp data by computing the percentages for each CEO, and averaging across CEOs.

As reported in Figure 3, median CEO pay levels in S\&P 500 Industrials has nearly tripled from less than $\$ 2.0$ million in 1992 to over $\$ 5$ million in 1998. The increase primarily reflects a dramatic growth in stock-based compensation, which swelled from $30 \%$ to $53 \%$ of total compensation, representing a five-fold increase in dollar terms. Most of the increase in stock-based compensation, in turn, reflects the growth in stock options grants, which grew from $23 \%$ of compensation in 1992 to $44 \%$ of compensation in 1998. (Over the same time period, the value of restricted stock and performance shares tripled in dollar value, but increased only slightly, $7 \%$ to $9 \%$, as a percentage of total compensation.) The biggest increase, both in dollar and percentage terms, was from 1997 to 1998, when median pay increased by nearly $\$ 1$ million (22\%) from its prior-year level.

The columns in Figure 3 represent an estimate of the company's cost of the CEO's pay package, and not the value of the package as perceived by the CEO recipient. Following our analysis of option valuation above, risk-averse undiversified executives will value all risky performance-based elements of their contract lower than their cost to the company. We extend our option-value methodology to measure executive-specific "risk-adjusted pay," defined as the certainty equivalent value of the full CEO pay package, and calculate riskadjusted pay levels for S\&P 500 CEOs from 1992 to 1998. The details of our methodology our relegated to Appendix A, but we extend equation (1) and (2) to allow for previously granted options, and extend (1) to include the full compensation package, including salaries, bonuses, stock options, restricted stock, and performance shares. Executive-specific data from Compustat or ExecuComp are available for all but two critical inputs: the executive's risk aversion and the executive's non-firm-related wealth. We compute risk-adjusted pay for relative risk aversion of $\rho=2$ and $\rho=3$, and (somewhat arbitrarily) assume that non-firmrelated wealth is equal to the greater of $\$ 5$ million or four times cash compensation.

In addition to showing the cost of the CEO's pay package, Figure 3 shows the median risk-adjusted pay for CEOs in S\&P 500 Industrials, based on two risk-aversion assumptions. Assuming that $\rho=2$ for all executives, median risk-adjusted pay grew from $\$ 1.6$ million in 1992 to $\$ 2.5$ million in 1998 , increasing by nearly $60 \%$ over the period. Assuming that $\rho=3$, median risk-adjusted pay grew from $\$ 1.4$ million in 1992 to $\$ 2.1$ million in 1998, increasing by about $50 \%$. In contrast, the cost of the median CEO's pay package increased by $160 \%$ over this period. Therefore, the growth in risk-adjusted pay is modest relative to the growth in unadjusted pay. Indeed, from 1997 to 1998 (when the median cost increased by $\$ 1$ 
million), the median risk-adjusted value of pay remained flat (assuming that $\rho=2$ ) or actually fell (assuming that $\rho=3$ ).

The modest growth in risk-adjusted pay levels (relative to the more-impressive growth in the cost of compensation) reflects, in part, the growing importance of stock options in executive pay packages. In addition, the recent "bull market" in the U.S. has made stockholding executives less diversified, which in turn has reduced the value of their current stock-based compensation. For example, the median stock and option holdings of the S\&P 500 Industrial executives in Figure 3 has grown from \$10 million in 1992 to nearly \$30 million in 1998.

One of the most widely noted findings in the executive compensation literature is that CEOs in utilities are paid less than CEOs in other sectors (Joskow, Rose and Wolfram, 1996; Murphy, 1999). However, it is also well-documented that utility CEOs hold less stock and receive less of their pay in the form of stock-based pay than do other executives. Table 2 explores the extent to which lower pay in utilities reflects that utility CEOs are better diversified and have less risky pay than do CEOs in non-utilities. The dependent variables are the logarithm of the total cost of the compensation package (that is, total pay without risk adjustments), and the logarithms of risk-adjusted pay with $\rho=2$ and $\rho=3$. Independent variables include logarithm of sales and dummy variables for finance and utility firms.

The coefficient on "Utility" in column (1) of Table 2 of -0.650 indicates that, after controlling for company size, the cost of CEO pay in utilities is $48 \%$ lower than pay in the general industry. ${ }^{49}$ The corresponding coefficients in columns (2) and (3) of -0.364 and -0.276 , respectively, indicate that risk-adjusted pay is $30 \%$ (when $\rho=2$ ) or $24 \%$ (when $\rho=3$ ) lower in utilities. Therefore, controlling for CEO diversification and the riskiness of pay explains a significant fraction-between a third and one-half-of the observed pay differences in utilities.

The regressions in Table 2 include year dummy variables from 1992 to 1997, with 1998 as the omitted category. The coefficient on the 1996 dummy variable in column (1) is negative and statistically significant, whereas the corresponding coefficients in columns (2) and (3) are positive but insignificant. Similarly, the coefficient on the 1997 dummy variable in column (1) is negative but insignificant, whereas the corresponding coefficients in

18 This comparison is derived from ExecuComp data; stock is measured at year-end prices and options are measured as the fiscal-year-end "spread" between the stock price and exercise price of all outstanding options (all amounts are in 1988-constant dollars).

19 Calculated as $e^{-.650}-1 \approx 0.48$. 
columns (2) and (3) are positive and statistically significant. These results suggest that, after controlling for company size and (broad) industry, risk-adjusted pay actually fell rather than rose between 1996 to 1998. Taken together, the risk-adjustments have dramatic effects on both the level and growth rates of CEO pay over time.

\section{Incentives from Executive Stock Options}

Executive stock options provide incentives to the extent that the recipients can affect the perceived value of their options. As demonstrated in Section 2, executive option values depend on the usual Black-Scholes parameters (stock price, exercise price, dividend yield, volatility, risk-free rate, and term) and also on the executive's risk-aversion, initial wealth, and diversification. Most of these parameters - including the exercise price, risk-free rate, term, risk aversion, and initial wealth - are outside management control once the option is granted. As a simplification, we ignore dividends (as we have throughout this paper) and treat an executive's stockholdings as exogenous. The effects of options on risk-taking, while interesting, are beyond the scope of this paper. ${ }^{4}$ We focus on the main incentive generated by stock option grants: how options affect the executive's motivation to increase the company's stock price.

Assuming executives understand how their actions affect share prices, option holdings provide incentives for executives to take actions that increase share prices, and avoid actions that decrease share prices. The incentives from a single option will naturally depend on the slope of the executive-value line, $\partial V / \partial P$, which defines how the certainty-equivalent value changes with an incremental change in the stock price. Figure 4 plots the slopes from the Black-Scholes and executive value lines illustrated in Figure 1 (which depicted the per-share cost and value of a grant of a ten-year option with an exercise price of \$30). The figure shows that the slope of the executive-value line is less than the slope of the Black-Scholes line, $\partial C / \partial P$, for undiversified executives. For example, when the stock price and exercise

20 Dividends can be easily incorporated into our model, and the results in this paper have been re-calculated for various dividend yields. We replicate the standard result that stock options provide incentives to reduce dividends (Lambert, Lanen, and Larcker, 1989), but do not generate any additional insights driven by diversification considerations.

21 Lambert, Larcker and Verrecchia (1991) produce the key insight with regard to options and risk-taking incentives. They show that, contrary to conventional wisdom, options can give risk-averse executives an incentive to reduce rather than increase risk-taking behavior. Although the Black-Scholes value of options increases with firm stock price volatility, the certainty-equivalent of options (executive value) can actually decrease when executives are risk-averse and undiversified. Similarly, Carpenter (1999) uses a dynamic portfolio choice model to show that option grants may reduce managerial risk-taking incentives. 
price are both $\$ 30$, the slope of the Black-Scholes function is 0.86 ( $86 \notin$ per $\$ 1$ price change), but the slope of the executive-value line is only 0.63 for an executive with $\rho=2$ and $50 \%$ of his wealth in company stock, and only .27 for an executive with $\rho=3$ and $67 \%$ of his wealth in stock. For a premium option granted with $\mathrm{P}=\$ 15$ and $\mathrm{X}=\$ 30$, the Black-Scholes slope is 0.63 compared to an executive-value slope of only 0.38 and 0.10 for executives with $\rho=2$, $50 \%$ in stock or, $\rho=3,67 \%$ in stock, respectively.

Many recent academic studies of executive incentives have followed Jensen and Murphy (1990) in defining the "pay-performance sensitivity" from stock options as the derivative of the Black-Scholes value with respect to the stock price. While this construct is an appropriate measure of how the market value of the executives' wealth (due to options) changes with stock prices, it overstates incentives from non-tradable options: at any stock price, the slope of the Black-Scholes line always exceeds the slope of the executive value line for risk-averse undiversified executives. As illustrated in Figure 4, measured payperformance sensitivities are particularly overstated for more risk-averse and less diversified executives, and for options that are deeply out-of-the-money.

\subsection{Implications}

\subsubsection{Incentive-Maximizing Exercise Prices}

One of the most striking facts about executive stock options is that the exercise price of virtually all options is set equal to the current stock price at the grant date. For example, 94\% of option grants to S\&P 500 CEOs in 1998 were at-the-money grants. In theory, however, exercise prices can be set below the grant-date stock price (discount options), above the grant-date stock price (premium options), or indexed to some industry or market index (indexed options). Setting the exercise price, like setting the "performance threshold" in any incentive plan, defines the standard against which performance is measured, and determines the likelihood of an ultimate payout.

We define the incentive strength from holding $n$ options as the change in the executive's value of those options with respect a change in the stock price, $\partial V(n) / \partial P$. Figure 4 suggests that the incentives from a single option are maximized when the stock price significantly exceeds the exercise price. But, we know from Figure 1 that discount options are much more costly to grant than at-the-money or premium options (that is, the BlackScholes cost is higher when the stock price significantly exceeds the exercise price). Herein 
lies the trade-off faced by the board when setting exercise prices for executive options: increasing the exercise price reduces the incentives of each option granted, but also reduces the company's cost of granting each option. Thus, holding the company's cost of granting options constant, the company can grant a few options at a low exercise price, or more options at a higher exercise price.

Solving for the optimal level of incentives requires information on the production function linking executive actions to stock prices, and the disutility function for those actions. Although solving for the optimal contract is beyond the scope of this paper, we can offer results on a narrower but related question: what exercise price maximizes incentives, holding constant the company's cost of granting options? Extrapolating from Grossman and Hart (1983), we imagine a two-stage process for deriving the optimal contract. In the first stage, we maximize incentives for an arbitrary company cost. In the second stage, we solve for the cost that maximizes company expected profits, given the results of the first stage. We offer results on the first stage, leaving the second stage to future research.

The company's "net cost" of granting options depends on whether the grant allows the company to reduce other forms of compensation. If the grant is an "add-on" to an existing compensation package, then the company's net cost is simply the opportunity cost or (as developed above) the Black-Scholes value of the grant, $n C(P)$. At the other extreme, suppose that an executive receives options valued at $V(n)$ while the company simultaneously lowers other forms of compensation by $V(n)$, leaving the executive with the same certaintyequivalent compensation. In this case, the net cost to the company of the option grant is $n C(P)$ - $V(n)$. Bertrand and Mullainathan (2000) report evidence suggesting that the appropriate cost assumption depends on the effectiveness of the company's corporate governance: options are an add-on in firms with weak governance, but are (at least partially) offset by decreases in cash compensation in firms with stronger governance. In order to capture both extremes, as well as intermediate cases, we define net cost as $n C(P)-\alpha V(n)$, where $0>\alpha>1$, and solve numerically for

$$
\underset{X}{\operatorname{MAX}} \frac{\partial V(n, X, P)}{\partial P} \text { subject to } n C(X, P)-\alpha V(n, X, P)=\mathrm{k} .
$$

Case 1: Options as an add-on $(\alpha=0)$. Figure 5 depicts the total incentives from a grant with a

22 In Grossman and Hart's original formulation, the first stage found the minimum cost way of implementing an arbitrary level of executive actions, and the second stage solved for the optimal action given the results of the first stage. Our approach is basically the "dual" of their approach, under the assumption of a one-forone correspondence between actions and incentives. 
Black-Scholes cost of $n C=\$ 300,000$ award as an add-on to existing compensation, for exercise prices varying from $0 \%$ (restricted stock) to $300 \%$ of the grant-date stock price. The executive is assumed to have $\$ 5$ million in wealth, split between non-firm-related cash and company stock ${ }^{23}$ The figure shows that the incentives for an executive with $\rho=2$ and $50 \%$ of his wealth in company stock are maximized by setting an exercise price equal to $130 \%$ of the market price of the stock on the date of grant. Incentive-maximizing exercise prices are lower for more risk-averse and less diversified executives: for an executive with $\rho=3$ and $67 \%$ of his wealth in company stock, incentives are maximized by setting an exercise price equal to only $40 \%$ of the grant-date market price.

Importantly, the incentive loci in Figure 5 are relatively flat around the maximum, suggesting that there is a range of exercise prices that yield "close to" maximum incentives. In Hall and Murphy (2000), we show that, for a wide range of parameters (including different Black-Scholes costs of the option grant), setting exercise prices at (or near) the grant-date market price maximizes pay/performance incentives for risk-averse, undiversified executives. US accounting rules, however, create a bias in favor at-the-money or premium options since discounted options and restricted stock create an accounting charge against earnings. Under the maintained assumptions, our analysis suggests that avoiding the accounting charge is not likely to be very costly to companies in terms of providing incentives. That is, even in cases where the optimal grant is a discount option, granting atthe-money options instead of discount options provides incentives that are nearly as strong.

In addition to showing how executive incentives vary with changes in the exercise price, Figure 5 also shows how the Black-Scholes' slope of options costing $n C=k$ varies with the exercise price. The figure shows that $\partial n C / \partial P$ is monotonically increasing throughout the depicted range. In fact, $\partial n C / \partial P$ is monotonically increasing for all exercise prices. This result suggests that, if managers valued stock options at their Black-Scholes value, pay/performance incentives could be increased without limit by giving increasingly more options at higher and higher exercise prices. This obviously incorrect result underscores the importance of introducing risk aversion into analysis of stock option incentives.

Case 2: Option Grant with Compensation Offset $(\alpha=1)$. Figure 6 depicts the total incentives from a grant with a net cost of $n C-\alpha V(n)=\$ 100,000$ award, where cash compensation is

23 Given our assumption of constant relative risk aversion, the dollar amounts are arbitrary. What matters is the grant size relative to the executive's initial wealth (in this case, $6 \%$ ). That is, we will get the same qualitative results if we assume (i) a $\$ 3000$ grant for an executive with $\$ 50,000$ in wealth; or (ii) a $\$ 60$ million grant for an executive with $\$ 1$ billion in wealth. 
reduced to keep the executive at the pre-grant expected utility. The figure indicates that in all cases, the exercise price that maximizes incentives is zero. That is, restricted stock, not options, provides the strongest incentives. This is not surprising given our earlier results. Figure 5 shows a relatively flat "incentive line" while Table 1 shows that executives strongly prefer, and therefore will "give up" more cash pay to receive options with very low exercise prices. When risk-averse, undiversified executives are "fully charged" for their equity-based pay through reductions in their cash compensation, restricted stock provides the strongest incentives. Restricted stock is relatively inexpensive (because executives value it close to its cost, creating a large offset to cash pay) and companies can therefore grant lots of it (for a constant cost).

Discussion. Our analysis points to an important connection between incentive-maximizing exercise prices and the pay-setting process. In the "add-on" case, exercise prices set close to the grant-date market prices maximize incentives. But, when executives give up cash compensation to receive equity-based pay, restricted stock provides stronger incentives than traditional options. Although there is clearly some charge for options in some companies (e.g., ECKO), the fact that options are almost always granted at-the-money combined with the fact that restricted stock is much rarer than options is evidence against the view that cash pay is always carefully offset against option pay in the way implied by (reasonably) competitive labor markets combined with strong governance.

Our analysis may also help explain the views of institutional investors and pay critics who applaud executive stock ownership, but criticize grants of restricted stock. ${ }^{5}$ We believe the criticism reflects that restricted stock is too-often an add-on to an existing competitive compensation package, and (consistent with our analysis) options provide stronger pay/performance incentives than restricted stock. However, to the extent that executives pay for the restricted stock (either through cash outlays or through reductions in other forms of compensation), restricted stock is a more efficient way to provide pay/performance incentives than options. Indeed, consistent with this analysis, boards controlled by venture capitalists and LBO associations - which are not loosely governed and plausibly "charge" their executives for the equity that is granted to them-very frequently use restricted stock

24 As before, it is also consistent with the view that the accounting charge created by discount options and restricted stock creates a strong bias against such pay, even when it is preferable in terms of pay/performance incentives.

25 See, for example, Graef S. Crystal, “Incentive Pay That Doesn’t Work,” Fortune (August 28, 1989). 
rather than options in order to pay their executives.

\subsubsection{Option Repricing}

One of the most controversial executive pay practices involves resetting the exercise price on outstanding options following a decline in the company's stock price (Saly, 1994). As shown in Figure 4, options lose incentive value once the stock price falls so far below the exercise price that the executive perceives little chance of exercising: this "loss of incentives" is a common justification for option "repricings" following share-price declines. Since repricing effectively "forgives" executives for dismal performance, companies adopting repricing policies create perverse incentives for executives holding options.

A recent twist on standard share-for-share repricing practices is "Black-Scholes repricing," in which the executives exchange their options with a high exercise price for a smaller number of options with a lower exercise price. The exchange is structured so that the total Black-Scholes value of the option is the same immediately before and after the exchange. From the executive's perspective, the exchange is beneficial since both options have the same expected value but the lower-priced options are less risky (i.e., have a higher probability of ultimately being exercised). From the shareholder's perspective, the cost is the same with or without the exchange. Executive incentives can either increase or decrease, depending on the specific parameters involved.

One of the first companies to adopt Black-Scholes repricing was General Dynamics in 1991. As described in Dial and Murphy (1995), the CEO of General Dynamics exchanged 105,000 options with an exercise price of $\$ 45$ (the market price on the original grant date) for 51,500 options with an exercise price of $\$ 25.50$ (the market price on the exchange date). The number of options offered in the exchange was determined to maintain the pre-exchange Black-Scholes cost of approximately $\$ 388,000$. Assuming that CEO Anders had risk aversion of $\rho=2$ and $\$ 4$ million in wealth (67\% in stock), he valued the 105,000 owt-of-themoney options at $\$ 190,000$ and the 51,500 at-the-money options at $\$ 255,000.7$ Clearly participating in the exchange made sense from Anders' perspective, while imposing little

26 In the case pre-IPO companies controlled by venture capitalists, managers often receive deeply discounted options (essentially stock).

27 Details of our calculation are available upon request, but are based on $\sigma=.2425$, dividend yield of $4 \%, \beta=$ $1, r_{f}=8 \%$, and $r_{m}-r_{f}=6.5 \%$. The $\$ 4$ million in total wealth is an assumption, but the $67 \%$ in stock is consistent with Anders' stock holdings (relative to the $\$ 4$ million). The new options were granted with a ten year term; the old options had nine years remaining. 
cost on the shareholders. According to our model, Anders' option incentives fell slightly from $\$ 18,500$ (the change in Anders' value of the old options for a $\$ 1$ change in the stock price) to $\$ 17,500$ (the change in his value of the new options for each $\$ 1$ change in stock prices).

\section{Early Exercise}

Our valuation analysis in Sections 2 and 3 assumed that executives hold options until their expiration date. However, in practice, executive options vest and become exercisable within a few years from grant, and executive (and employee) options are routinely exercised relatively early in their term (Huddart and Lang, 1996). In this section, we relax our maintained assumption that executives hold their options until the expiration date and analyze the decision to exercise early. ${ }^{28}$ In particular, we analyze how the company's cost, the executive's value, and the incentive strength are affected by allowing early exercise. In order to isolate how risk aversion and diversification drive executive exercise decisions, we continue to ignore dividends. While investors holding freely tradable American call options on non-dividend paying stocks will never exercise early (Merton, 1973), we show that riskaverse executives holding non-tradable options will exercise early to "lock in" an option gain.

\subsection{Methodology}

We analyze executive option values and early exercise decisions using a modified binomial approach, described in detail in Appendix B. Our approach is similar to traditional binomial option valuation (Cox, Ross, and Rubinstein, 1979) with two major differences. First, while binomial price "trees" under the traditional model are based on expected returns equal to the risk-free rate (reflecting that option holders perfectly hedge the risk of options), price trees under our modified approach are based on CAPM expected returns, $E(r)=r_{f}+\beta\left(r_{m}-r_{f}\right)$. Second, while under the traditional approach the payout from exercising is

28 Related analyses of early-exercise decisions include Huddart (1994), Carpenter (1998), and DeTemple and Sundaresan (1999). Our framework for analyzing early exercise is closest to Huddart's (1994), who focuses primarily on measuring the cost of options to the firm. Relative to his model, our framework allows the executive to hold a richer set of assets prior to exercise - cash, stock and options rather than options onlyand employs a more flexible utility framework.

29 For evidence that (non-rational) psychological factors may also play a role in the exercise decisions of employees, see Heath, Huddart and Lang (1999). 
compared to the expected value of holding for another period, under our modified approach we compare the expected utility from exercising (and holding cash until the final period) to the "expected" expected utility from holding the option for another period. We estimate the executive value of the option grant by finding the grant-date cash award (invested until $\mathrm{T}$ at the risk-free rate) that yields the expected utility at the first node of the binomial tree.

We assume that stock acquired through exercise is sold immediately, with the cash proceeds invested at the risk-free rate. ${ }^{9}$ In addition, we assume that options are exercisable immediately upon grant (alternative vesting schedules are analyzed below in Section 4.4) We maintain our other assumptions from Sections 2 and 3. In particular, we assume the option is granted for $\mathrm{T}=10$ years at an exercise price of $\mathrm{X}=\$ 30$ (the grant-date market price), and assume $\sigma=.30, \beta=1 r_{f}=6 \%$, and $r_{m}-r_{f}=6.5 \%$. We compute executive values for a grant of 5,000 options for executives with constant relative risk aversion of $\rho=2$ or $\rho=3$ and holding either $50 \%$ or $67 \%$ of their $\$ 5$ million initial wealth in company stock. Our binomial tree is calculated for $h=50$ periods per year, or a total of $h T=500$ periods and 125,250 individual nodes. For each node, we record information on the stock price, the expected utility, and an indicator for whether the option has been exercised.

\subsection{Early-Exercise Decisions}

Undiversified executives with exercisable options face a tradeoff. If they exercise early, they can invest the "spread" between the market and exercise price at the risk-free rate, thereby locking in the gain. However, by exercising early (and immediately selling the acquired shares), they sacrifice both upside potential in stock prices and the ability to defer payment of the exercise price. The exercise decision in each period will naturally depend on the realized stock price (relative to the exercise price). If the price is sufficiently high, the expected utility from locking in the gain will exceed the utility from holding the option for another period. But, at sufficiently low stock prices, even risk-averse, undiversified executives will not exercise options early.

We define the "threshold price" as the stock price where the executive is just indifferent between exercising early or holding the option for another period. Figure 7 shows how the threshold price varies over the 10-year term of the option for managers with the

30 Ignoring taxes, which we do throughout, it would be irrational for an executive to exercise an option early and to hold the stock. 
same pairs of risk aversion and diversification as before. ${ }^{\text {St }}$ Several results emerge. First, in any period, more risk-averse and less diversified executives have lower threshold prices (that is, they will choose to exercise early at lower realized stock prices). For example, an executive with $\rho=2$ and half of his wealth in company stock has a first-year price threshold of more than $\$ 90$. The price would have to more than triple (from its $\$ 30$ initial value) in the first year for such an executive to exercise early. However, a more risk averse $(\rho=3)$ and less diversified (67\% of his wealth in stock) executive has a first-year exercise price boundary of less than $\$ 60$.

Second, Figure 7 reveals that threshold prices decrease over time. As time passes, the benefits of holding the option (deferring the payment of the exercise price, and missing out on future price increases) fall, and an executive's threshold for locking in option gains is lower. On the expiration date, of course, the threshold price falls to the exercise price (in this case, \$30). But, the day before exercise, the threshold price is above $\$ 50$ for an executive with $\rho=2$ and $50 \%$ of his initial wealth in stock, and about $\$ 35$ for an executive with $\rho=3$ and $67 \%$ of his initial wealth in stock.

Figure 8 shows the cumulative probabilities of early exercise for executives. ${ }^{2}$ The figure indicates that there is a relatively high probability of early exercise after the first two years, although the probabilities differ greatly (consistent with the very different threshold prices in Figure 7) with differences in risk aversion and diversification. For example, the likelihood that a (relatively) high-risk-aversion $(\rho=3)$ and low-diversification (wealth in stock at 67\%) executive will exercise within the first 4 years is about $50 \%$, and within 8 years is $75 \%$. Conversely, an executive with $\rho=2$ and $50 \%$ of his wealth in stock has only an $18 \%$ chance of exercising within the first 4 years, and $50 \%$ chance of exercising within the first eight years. As of the day before expiration, the cumulative exercise probabilities range from $65 \%$ (for a $\rho=2,50 \%$ executive) to $84 \%$ (for a $\rho=3,67 \%$ executive). Since all in-the-money options are exercised in the last period, the cumulative probabilities of exercise by the expiration day are quite close for executives with different characteristics, ranging

31 Within our binomial framework, we estimate the threshold price for each period as the average of the lowest price that induces early exercise and the highest price that induces holding the option for another period. Because of the discreteness in the binomial model (which considers only " $n$ " possible stock prices in the $\mathrm{n}^{\text {th }}$ period), our estimated threshold prices vary within a range from period to period (depending, for example, on whether " $\mathrm{n}$ " is even or odd in a period). As an expositional simplification, the threshold prices in Figure 7 have been smoothed somewhat by using linear interpolation and a larger number of periods per year $(\mathrm{h}=75$ rather than 50$)$ than in the rest of the analysis.

32 The probabilities are based on a simulation with 100,000 sample price paths (through the tree). At each period $t$, the cumulative probability of early exercise is calculated as the percentage of price paths (out of $100,000)$ that surpassed the threshold price at t or earlier. 
from 78 percent to 85 percent.

Early exercise is therefore consistent with our framework: risk-averse executives will exercise early following price run-ups to "lock in" a gain. This result has important implications for the value, cost, and incentive strength of executive stock options, discussed at length in the following section.

\subsection{Cost, Value, and Incentives}

Allowing executives to exercise prior to the full term affects both the cost and value of executive stock options. Allowing early exercise unambiguously increases the value of an option to an undiversified executive, since executives could always hold the option to full term but in practice choose not to. In contrast, allowing early exercise actually reduces the company's cost of granting an option. As discussed in Section 2, the economic cost of granting an option is the amount the company could have raised if it were to sell the option to an outside investor instead of giving it to the executive. If outside investors made the exercise decision, then the company's cost would be the usual binomial valuation of an American option (which, for non-dividend-paying stocks, is simply the Black-Scholes value). But, in this case, the exercise decision is not made by the investor but rather by an executive who for a variety of reasons is not expected to make the same exercise decisions as an unrestricted outside investor. Since the executive exercise decisions are suboptimal from the standpoint of the outside investor, the amount the investor is willing to pay for the option is clearly reduced when exercise decisions are made by the executive, rather than by the investor.

The cost reduction comes from the fact that early exercise essentially removes the right-hand tail of payoffs to executive option holders, who truncate the huge payoffs that would otherwise come from dramatic increases in the company's stock price. For example, consider the executives who prematurely exercised their options in the mid-1990s at Cisco, Microsoft, General Electric and other high-flying companies of the decade. Such early exercises led to far lower company costs than would have been the case if these executives had not exercised their options early.

As before, we measure the value of an immediately exercisable executive option as the grant-date cash award that yields the expected utility as receiving an option, and measure the

33 The difference reflects options that were in-the-money earlier in the term (and exercised by high riskaverse low diversified executives), but out-of-the-money at expiration. 
incentives from the option as the slope of the executive-value line, $\partial V / \partial P$, which defines how the option value changes with an incremental change in the stock price. We measure the cost of the executive option as the usual binomial valuation of an American option (under risk-neutral pricing) but with a catch: the exercise decision is made by an undiversified executive rather than by the investor. In particular, we measure the cost of the option under the assumption that the investor is "forced" to exercise when even the stock price exceeds the threshold prices in Figure 7 .

Table 3 shows how the company's cost, the executive's value, and incentives (defined as the derivative of value with respect to changes in stock prices) are affected by the possibility of early exercise for various pairs of risk aversion and diversification. The data depict the per-share costs, value, and incentives from a grant of 5,000 ten-year stock options with an exercise price of $\$ 30$ (the market price on the date of grant). The columns under "Options Exercisable at Expiration" basically replicate the results in Table 1 (for an at-themoney grant): the cost is the Black-Scholes cost of $\$ 16.55$, executive values range from $\$ 3.49$ to $\$ 10.51$, and the incentives range from $\$ 0.17$ to $\$ 0.45$. The calculations under "Options Exercisable at Grant" allow executives to exercise options anytime during their term. Compared to the case without early exercise, the company's cost is lower, and the executive's value and incentives are higher, for grants that allow early exercise. For example, for an executive with $\rho=2$ and $67 \%$ of his wealth in company stock, allowing early exercise increases his value from $\$ 7.41$ to $\$ 9.96$, while reducing the company's cost of granting the option from $\$ 16.55$ to $\$ 13.60$.

In addition to increasing executive value while reducing company cost, Table 3 shows that allowing early exercise also increases executive incentives. For example, for an executive with $\rho=2$ and $50 \%$ of his wealth in stock, a one dollar increase in the stock price will increase the value of an option without an early exercise provision by only $45 \phi$, but will increase the value of an otherwise identical exercisable option by 61ф. Allowing early exercise doubles the option incentives for a $\rho=3$ and $50 \%$ executive (from $26 \phi$ to $53 \phi$ ), and nearly triples the incentives for a $\rho=3$ and $67 \%$ executive.

Overall, our results help explain not only why executive options are so often exercised early, but why it is in the interest of shareholders to allow early exercise. Early exercise reduces the company's cost of granting options, while increasing both the value to the executive recipient and the grant-date incentive strength of the options. Of course, to the

34 Formally, we compute the value of a path-dependent barrier option (Hull, 1997), where the barrier (the price path above which the executive exercises) varies over time as shown in Figure 7. 
extent that exercised options are replaced with new grants, early-exercise provisions may increase the total number of options granted in the long run; such dynamic issues are interesting but are beyond the scope of our current study.

\subsection{Vesting Schedules}

The analysis so far in this section has assumed that options are immediately exercisable upon grant, and can be freely exercised at anytime during the term of the option. In practice, however, options typically become exercisable only when they "vest" (that is, when the options are no longer subject to forfeiture if the executive leaves the firm). Although there is a range of observed practices, the most common schedules vest options $33 \%$ annually over three years, $25 \%$ annually over four years, or $20 \%$ annually over five years.

Huddart and Lang (1996) have noted that executives (and employees) exercise a disproportionate number of options immediately upon vesting, creating spikes in optionexercise patterns. Table 4 replicates this empirical result for our hypothetical risk-averse, undiversified executives. The table shows the likelihood of exercising on the vesting date, for options with cliff-vesting in two, three, or four years. For example, the table shows that an executive with $\rho=3$ and $67 \%$ of his wealth in company stock has a $17 \%$ chance of exercising his options on the vesting date if they vest in two years, and a $33 \%$ chance if they vest in four years. The spike is naturally smaller for executives who are more risk tolerant and more diversified: the likelihood of exercising on the vesting date for a $\rho=2,50 \%$ executive is only $1.4 \%$ for options vesting in two years, and $10 \%$ for options vesting in four years.

Table 3 showed that allowing early exercise reduced the company's cost of granting the option and increasing the perceived value of the option to the executive. Therefore, the ratio of the executive's value to the company's cost is higher for companies with immediately exercisable options than for companies not allowing early exercise. Figure 9 plots the intermediate cases, showing value:cost ratios for option grants with vesting periods that range from 0 years (complete early exercise is allowed) to 10 years (no early exercise is allowed).

Two primary results emerge from Figure 9. First, the value:cost ratios fall more dramatically in the cases in which executives are more risk-averse and less diversified. Second, the value:cost ratios are very flat at low vesting durations, especially in cases in which risk-aversion is relatively low and diversification is relatively high. This result 
suggests that shortening already short vesting periods does not increase the value:cost inefficiency of options very much. To the extent that short vesting periods create benefits to companies - in terms of retention and ensuring that options are held and provide positive incentives for some minimum period of time-our analysis suggests that the counterbalancing "inefficiency" costs of short vesting may not be too large. Thus, this analysis helps explain why short vesting periods are so common while longer vesting periods (of more than five years) are virtually non-existent.

\section{Conclusion}

Risk aversion combined with non-diversification drives a wedge between the company cost and the executive value of stock options. The result that risk affects compensation is not new: economists have long understood that individuals demand compensating differentials for bearing risk, and the tradeoff between risk and incentive compensation lies at the heart of agency theory (Haubrich, 1994; Aggarwal and Samwick, 1999). However, the implications of adjusting stock-option compensation for risk have not been explored extensively. Indeed, although academics and practitioners sometimes note the shortcomings of Black-Scholes, academics routinely use Black-Scholes to measure the value, cost and pay/performance sensitivity of non-tradable executive options, and practitioners routinely use Black-Scholes (or some non-risk adjusted modification) in order to "measure" option compensation, conflating value and cost.

We use a certainty-equivalent approach to derive the risk-adjusted "Executive Value" of a non-tradable option, and compute the "value:cost" ratio by dividing this value by the company's cost. We show that value:cost ratios are lower for more risk-averse and less diversified executives, and that value:cost ratios are higher for options that are in-the-money or have provisions allowing early exercise. More broadly and most importantly, we show that understanding this divergence between value and cost explains, or provides insight about, virtually every major stock option practice, ranging from option design to executive behavior.

Our results help justify, for example, why executives often claim that Black-Scholes values are too high and why they demand large premiums for accepting stock options in lieu 
of cash compensation. In addition, and largely consistent with practice, our results suggest that granting at-the-money options maximizes incentives when grants are an add-on to existing pay packages, while restricted stock is preferred when grants are in lieu of existing cash compensation. We also use our framework to analyze option repricings and show that cost-neutral repricings can benefit both shareholders and executives. Finally, our results are consistent with a variety of stylized facts regarding early exercise policies and behavior. We show why both executives and shareholders benefit from early-exercise provisions, why executives routinely exercise options on their vesting dates, and why (relatively) shortvesting periods are the norm.

Our results have important implications for future research in executive compensation and lead to reinterpretation of existing research. Studies of time-trends in executive compensation have documented a rapid growth in executive pay levels over the past decade, driven by the dramatic growth in (Black-Scholes measures of) option compensation. We show that after adjusting for the riskiness of equity-based pay, the increase in "pay" levels has plausibly been relatively modest (although there has been a dramatic growth in the cost of executive compensation). In addition, we show that much of the observed difference in pay across industries (for example, between manufacturing and utility executives) can be explained by differences in the riskiness of pay. These findings suggest that analyses of pay levels that fail to account for risk can produce misleading results. For the same reason, we argue that studies of pay-performance sensitivities based on changes in Black-Scholes values can produce misleading results, and we therefore introduce a conceptually cleaner measure of pay-performance sensitivity: the derivative of Executive Value with respect to the stock price.

Although our analysis has focused on stock options, our framework is general and applies to all risky components of pay. One of the key results of this paper is that options are a particularly expensive way to convey compensation. But the same is true for risky bonuses and other forms of contingent pay. There are important incentive benefits to both types of pay (obviously, since without such benefits, our analysis suggests that companies would never offer risky pay), but there is a strong need for a framework for researchers and practitioners to understand, and quantify, the value:cost efficiency of all forms of risky compensation. Moreover, this need continues to grow as companies increasingly put higher 
percentages of pay at risk for increasingly higher percentages of their managers and employees, a trend that also appears to be spreading far beyond the borders of the US. We believe that there is a high return to future research that broadens our framework in precisely this way. 


\section{References}

Abowd, John M. and David S. Kaplan, "Executive Compensation: Six Questions That Need Answering," Journal of Economic Perspectives, Volume 13, Number 4, Fall, 1999, 145-168.

Aggarwal, Rajesh K. and Andrew A. Samwick (1999), "The Other Side of the Tradeoff: The Impact of Risk on Executive Compensation," Journal of Political Economy, 107, 65105.

Bertrand, Marianne and Sendhil Mullainathan, "Do CEOs Set Their Own Pay? The Ones Without Principals Do,” NBER working paper 7604, March 2000.

Bettis, J. Carr, John M. Bizjak, and Michael L. Lemmon (1999) "Insider Trading in Derivative Securities: An Empirical Examination of the Use of Zero-Cost Collars and Equity Swaps by Corporate Insiders.” Arizona State University.

Black, F. and M. Scholes (1973), "The Pricing of Options and Corporate Liabilities," Journal of Political Economy, 81, 637-59.

Carpenter, Jennifer (1998), "The Exercise and Valuation of Executive Stock Options," Journal of Financial Economics, 48(2): 127-158.

Carpenter, Jennifer (1999), "Does Option Compensation Increase Managerial Risk Appetite?," forthcoming in the Journal of Finance.

Cox, John C., Steven R. Ross, and Mark Rubinstein (1979), Option Pricing: A Simplified Approach, Journal of Financial Economics, 7, 229-263.

DeTemple, Jerome and Suresh Sundaresan (1999), Nontraded Asset Valuation with Portfolio Constraints: A Binomial Approach, The Review of Financial Studies, 12 (4), 835-872.

Dial, Jay and Kevin. J. Murphy (1995), "Incentives, Downsizing, and Value Creation at General Dynamics," Journal of Financial Economics, 37(3), 261-314.

Grossman, Sanford J. and Oliver D. Hart, "An Analysis of the Principle-Agent Problem," Econometrica, Vol. 51, No. 1, January, 1983, 7-45.

Hall, Brian J. and Jeffrey B. Liebman (1998), "Are CEOs Really Paid Like Bureaucrats?" Quarterly Journal of Economics, 113, August, 653-691.

Hall, Brian J. and Kevin J. Murphy (2000), "Optimal Exercise Prices for Risk Averse Executives," American Economic Review, May, 209-214.

Haubrich, Joseph (1994), "Risk-Aversion, Performance Pay and the Principal-Agent Problem," Journal of Political Economy, 102 (2), 258-276. 
Heath, Chip, Steven Huddart, and Mark Lang (1999), "Psychological Factors and Stock Options Exercises," Quarterly Journal of Economics, 114, May, 601-628.

Himmelberg, Charles P. and R. Glenn Hubbard (2000), "Incentive Pay and the Market for CEOs: An Analysis of Pay-for-Performance Sensitivity," Columbia University.

Huddart, Steven (1994), "Employee Stock Options," Journal of Accounting and Economics, $18,207-231$.

Huddart, Steven and Mark Lang (1996), "Employee Stock Options Exercises: An Empirical Analysis, Journal of Accounting and Economics, 21, 5-43.

Hull, John (1997), Options, Futures, and Other Derivative Securities, 3rd Edition, Prentice Hall: New Jersey.

Jensen, M. and K. J. Murphy (1990), "Performance Pay and Top-Management Incentives," Journal of Political Economy, 98(2), 225-64.

Joskow, Paul, Nancy Rose and Catherine Wolfram (1996), "Political Constraints on Executive Compensation: Evidence from the Electric Utility Industry," RAND Journal of Economics, 27 (1), 165-182.

Kulatilaka, Nalin and Alan J. Marcus (1994), "Valuing Employee Stock Options," Financial Analysts Journal, November- December, 46-56.

Lambert, R., W. Lanen, and D. Larcker (1989), "Executive Stock Option Plans and Corporate Dividend Policy," Journal of Financial and Quantitative Analysis, 24(4), 409-425.

Lambert, Richard A.; Larcker, David F. and Verrecchia, Robert E. (1991), "Portfolio Considerations in Valuing Executive Compensation," Journal of Accounting Research, 29(1), 129-49.

Merton, Robert C. (1997), Continuous-Time Finance, Blackwell Publishers.

Merton, Robert C. (1973) "Theory of Rational Option Pricing," Bell Journal of Economics and Management Science, IV, 141-183.

Meulbroek, Lisa K., "The Efficiency of Equity-Linked Compensation: Understanding the Full Cost of Awarding Executive Stock Options,” HBS working paper, 2000.

Murphy, Kevin J.. (1999) "Executive Compensation,” in Orley Ashenfelter and David Card, eds., Handbook of Labor Economics, Vol. III, North Holland.

Oyer, Paul (2000), "Why Do Firms Use Incentives That Have No Incentive Effects?" Stanford University. 
Rubenstein (1995), “On the Accounting Valuation of Employee Stock Options," Journal of Derivatives, Fall.

Saly, J. (1994), "Repricing Executive Stock Options in a Down Market," Journal of Accounting and Economics, 18(3), 325-356. 


\section{Appendix A}

\section{Risk-Adjusted Pay Calculations}

Our risk-adjusted pay calculations for S\&P 500 executives are based on the following data available from Compustat's ExecuComp (unless otherwise sourced):

s Shares of stock owned,

$n_{0} \quad$ Number of previously granted options held at year-end,

$X_{0}$. Average exercise price for previously granted options,

Salary Base salary plus all non-variable compensation,

Bonus Bonus plus the target award from accounting-based long-term plans,

$n_{i} \quad$ Number of shares in the $i^{\text {th }}$ option, restricted stock, or target performanceshare grant,

$X_{i} \quad$ Exercise price for the $i^{\text {th }}$ option grant (equals 0 for restricted stock and performance-share grants),

T Option term

$\sigma \quad$ Annualized standard deviation of continuous returns, measured over 48 months,

$\beta \quad$ Equity beta, calculated from monthly data over 48 months,

$r_{f} \quad$ Average yield on U.S. government securities over the fiscal year (Source: Federal Reserve System),

$\left(r_{m}-r_{f}\right) \quad$ Equity premium (assumed to be $\left.6.5 \%\right)$.

In calculating risk-adjusted pay we also make assumptions regarding executive relative risk aversion, $\rho$, and non-firm-related wealth, $w$. Our calculations are based on $\rho=2$ or $\rho=3$, assuming that $\mathrm{w}$ is equal to the greater of $\$ 5$ million or four times cash compensation. In addition, we (somewhat arbitrarily) discount Bonuses by $20 \%$, to account for the risk in bonuses. Assuming that $w$, Salary, and Bonus is invested at the risk-free rate, $r_{f}$, and that the realized stock price at $T$ is $P_{T}$, the executive's wealth at time $T$ is given by

$$
\begin{gathered}
W_{T} \equiv w\left(1+\mathrm{r}_{\mathrm{f}}\right)^{T}+s P_{T}+n_{0} \bullet \max \left(0, P_{T^{-}} X_{0}\right)+ \\
\left(\text { Salary }+.8^{*} \text { Bonus }\right)\left(1+r_{f}\right)^{T}+\sum n_{i} \bullet \max \left(0, P_{T^{-}} X_{i}\right),
\end{gathered}
$$


where the summation in $\sum n_{i} \bullet \max \left(0, P_{T^{-}} X_{i}\right)$ allows for multiple option and stock grants. ${ }^{\text {If, }}$ instead of the option, he were awarded $V$ in cash that he invested at the risk-free rate, his wealth at time $T$ would be:

$$
W_{T} \equiv(w+V)\left(1+r_{f}\right)^{T}+s P_{T}+n_{0} \bullet \max \left(0, P_{T}-X_{0}\right)
$$

As before, we assume the executive's utility over wealth is $U(W)$ with constant relative risk aversion, and define the executive's risk-adjusted compensation as the certainty equivalent $V$ that equates the expected utilities of (1) and (2):

$$
\int U\left(W_{T}^{V}\right) f\left(P_{T}\right) d P_{T} \equiv \int U\left(W_{T}\right) f\left(P_{T}\right) d P_{T}
$$

where the distribution of stock prices in $T$ years is lognormal with volatility $\sigma$ and expected value equal to $\left(r_{f}+\beta\left(r_{m}-r_{f}\right)-\sigma^{2} / 2\right) T$.

35 Our methodology requires that the grant-date market price and the expiration term be the same for all grants made to a single executive during the year. When grants were made at different dates (and different prices), we "normalized" the price by adjusting the exercise price and the shares granted. When grants were made for various terms, we used the term for the largest grant. This restriction was seldom required: $98 \%$ of the sample executives had only single grants or multiple grants with a common expiration term. 


\section{Appendix B}

\section{A Binomial Framework for Non-tradable Options}

We begin by building a traditional binomial tree (Cox, Ross, and Rubinstein, 1979), starting with an initial stock price of $P_{0}$. The stock prices in the second period are either $P_{0} \lambda$ (with probability $\pi$ ) or $P_{0} / \lambda$ probability $1-\pi$; subsequent prices are determined similarly for $h$ periods per year and $Y$ years (the total number of periods is $T \equiv Y h$ ). In the traditional model with risk-neutral growth, the probabilities $\pi$ are determined so that the expected return is the risk-free rate. We depart from the traditional model by assuming an expected continuously compounded annual return of $\mu \equiv \ln \left(1+r_{f}+\beta\left(r_{m}-r_{f}\right)\right)$ and (therefore) a per-period return of $m \equiv e^{\mu / h}$. The "uptick" $\lambda$ and probability $\pi$ are chosen to solve:

$$
\begin{gathered}
\pi \lambda+(1-\pi)(1 / \lambda)=m, \\
\pi \lambda^{2}+(1-\pi)(1 / \lambda)^{2}-m^{2}=\gamma,
\end{gathered}
$$

where $\mathrm{m}$ and $\gamma \equiv m^{2}\left(e^{\sigma^{2 / h}}-1\right)$ are (respectively) the mean and variance of the assumed lognormal distribution of stock prices. Applying the quadratic formula,

$$
\begin{gathered}
\lambda=\frac{1}{2 m}\left(\left(m^{2}+\gamma+l\right)-\sqrt{\left(m^{2}+\gamma+1\right)^{2}-4 m^{2}}\right), \\
\pi=\frac{m-\frac{1}{\lambda}}{\lambda-\frac{1}{\lambda}} .
\end{gathered}
$$

In order to determine executive option values and early exercise decisions, we employ a backward induction algorithm combined with same utility function (and parameter assumptions) used in our previous analysis. As before, we assume the executive holds nonfirm-related wealth, $w$, invested at the risk-free rate, $r_{f}$, holds $s$ shares of company stock, and is given a grant of $n$ options at exercise price $X$. If the executive decides to exercise his options early, the profits from the exercise are invested in the riskless asset, which is then held until the final period.

The executive's exercise decision rule is: exercise at any period $t$ if the expected utility from exercise is greater than the expected utility from holding the option to the next period. Specifically, utility based on final period $\mathrm{T}$ wealth is calculated at each final period node. (The final period exercise decision is trivial since, at in-the-money nodes, all options will be exercised, and at out-of-the-money nodes, all options expire worthless.) Then, in the period prior to the final period (T-1), the executive solves: 


$$
\left.\operatorname{Max}\left\{\pi U_{T}^{+}+(1-\pi) U_{T}^{-}\right), U_{T-1}^{E}\right\}
$$

where $U_{T}^{+}$is the expected utility in T if the stock price increases by $\lambda$ (an uptick), $U_{T}^{-}$is the expected utility in $T$ if the stock price increases by $1 / \lambda$ (a downtick), and $U_{T-1}^{E}$ is the expected if utility in $T-1$ if the executive exercises in $T-1$. Evaluating utility in the event of exercise is straightforward since no further decisions are made by the executive. Expected utility under early exercise is based on post-exercise holdings of safe wealth and stock evaluated at all possible (given the current node) final-period stock prices. Following evaluation at $T-1$, the same process is repeated at $T-2$ and backward induction is then used until the root node is reached and the tree is fully grown. At completion, each of the $n Y$ nodes of the final tree contains a stock price $P_{t, i}$, an expected utility, and an indicator for whether the option has been exercised.

The expected utilities in each node of the binomial tree assume cash, stock, and options are held until period $\mathrm{T}$, and therefore denote final-period utilities. We estimate the executive value of the option grant by finding the grant-date cash award (invested until $\mathrm{T}$ at the riskfree rate) that yields the expected utility at the first node of the binomial tree. 
Table 1

Ratio of Executive Value to Black-Scholes Cost for Option with \$30 Exercise Price, for Various Pairs of Relative Risk Aversion ( $\rho$ ) and Diversification

\begin{tabular}{|c|c|c|c|c|c|c|}
\hline $\begin{array}{l}\text { Stock } \\
\text { Price }\end{array}$ & $\begin{array}{l}B-S \\
\text { Cost }\end{array}$ & $\begin{array}{c}\rho=2 \\
50 \% \text { Stock }\end{array}$ & $\begin{array}{c}\rho=2 \\
67 \% \text { Stock }\end{array}$ & $\begin{array}{c}\rho=3 \\
50 \% \text { Stock }\end{array}$ & $\begin{array}{c}\rho=3 \\
67 \% \text { Stock }\end{array}$ & $\begin{array}{c}\text { Payout } \\
\text { Probability }\end{array}$ \\
\hline$\$ 5$ & $\$ 0.39$ & $24.5 \%$ & $13.4 \%$ & $5.8 \%$ & $2.2 \%$ & $13.1 \%$ \\
\hline$\$ 15$ & $\$ 4.95$ & $49.7 \%$ & $31.6 \%$ & $22.3 \%$ & $10.7 \%$ & $51.5 \%$ \\
\hline$\$ 30$ & $\$ 16.55$ & $63.5 \%$ & $44.8 \%$ & $36.7 \%$ & $21.1 \%$ & $77.9 \%$ \\
\hline$\$ 45$ & $\$ 30.11$ & $69.1 \%$ & $51.2 \%$ & $44.0 \%$ & $27.8 \%$ & $88.4 \%$ \\
\hline$\$ 60$ & $\$ 44.40$ & $71.9 \%$ & $54.9 \%$ & $48.0 \%$ & $32.0 \%$ & $93.3 \%$ \\
\hline
\end{tabular}

Note: B-S cost is the Black-Scholes value of one option with an exercise price of $\$ 30$. Executive values are estimated numerically assuming that the executive has constant relative risk aversion, $\rho=2$ or $\rho=3$, and assuming (using the Capital Asset Pricing Model, CAPM) that the distribution of stock prices in T=10 years is lognormal with volatility $\sigma=.30$ and expected value $\left(r_{f}+\beta\left(r_{m}-r_{f}\right)-\sigma^{2} / 2\right) T$, where $\beta=1$ is the firm's systematic risk, $r_{f}=6 \%$ is the risk-free rate, and $r_{m}-r_{f}=$ $6.5 \%$ is the equity premium. The payout probability that the market price at expiration, $P_{T}$, exceeds the exercise price, $X$, is calculated under the standard CAPM assumption that $\operatorname{Ln}\left(P_{T} / P_{0}\right)$ is normally distributed with mean $\mu \equiv \operatorname{Ln}\left(r_{f}+\beta\left(r_{m}-r_{f}\right)\right.$ $\left.\sigma^{2} / 2\right) T$ and variance $\sigma^{2} T$. 
Table 2

Explanatory Regressions for Risk-Adjusted and Unadjusted Pay for S\&P 500 CEOs

\begin{tabular}{|c|c|c|c|}
\hline \multirow{3}{*}{ Independent Variable } & \multicolumn{3}{|c|}{ Dependent Variables: CEO Total Compensation } \\
\hline & $\begin{array}{c}\text { No Risk } \\
\text { Adjustment }\end{array}$ & $\begin{array}{l}\text { Risk-Adjusted } \\
\text { with } \rho=2\end{array}$ & $\begin{array}{l}\text { Risk-Adjusted } \\
\text { with } \rho=3\end{array}$ \\
\hline & $(1)$ & $(2)$ & (3) \\
\hline Intercept & $\begin{array}{c}5.90 \\
(49.7)\end{array}$ & $\begin{array}{c}4.97 \\
(49.4)\end{array}$ & $\begin{array}{c}4.96 \\
(51.2)\end{array}$ \\
\hline Ln(Sales) & $\begin{array}{l}0.302 \\
(23.2)\end{array}$ & $\begin{array}{l}0.332 \\
(30.2)\end{array}$ & $\begin{array}{l}0.311 \\
(29.4)\end{array}$ \\
\hline Finance (Dummy) & $\begin{array}{l}0.226 \\
(5.4)\end{array}$ & $\begin{array}{l}0.310 \\
(8.8)\end{array}$ & $\begin{array}{l}0.306 \\
(9.0)\end{array}$ \\
\hline Utility (Dummy) & $\begin{array}{l}-0.650 \\
(-12.4)\end{array}$ & $\begin{array}{c}-0.364 \\
(-8.2)\end{array}$ & $\begin{array}{c}-0.276 \\
(-6.5)\end{array}$ \\
\hline Year 1992 (Dummy) & $\begin{array}{l}-0.766 \\
(-13.8)\end{array}$ & $\begin{array}{l}-0.327 \\
(-6.9)\end{array}$ & $\begin{array}{l}-0.243 \\
(-5.4)\end{array}$ \\
\hline Year 1993 (Dummy) & $\begin{array}{l}-0.621 \\
(-11.2)\end{array}$ & $\begin{array}{l}-0.238 \\
(-5.1)\end{array}$ & $\begin{array}{l}-0.161 \\
(-3.6)\end{array}$ \\
\hline Year 1994 (Dummy) & $\begin{array}{l}-0.519 \\
(-9.5)\end{array}$ & $\begin{array}{l}-0.139 \\
(-3.0)\end{array}$ & $\begin{array}{l}-0.079 \\
(-1.8)\end{array}$ \\
\hline Year 1995 (Dummy) & $\begin{array}{l}-0.400 \\
(-7.4)\end{array}$ & $\begin{array}{l}-0.046 \\
(-1.0)\end{array}$ & $\begin{array}{l}-0.005 \\
(-0.1)\end{array}$ \\
\hline Year 1996 (Dummy) & $\begin{array}{l}-0.221 \\
(-4.1)\end{array}$ & $\begin{array}{l}0.058 \\
(1.3)\end{array}$ & $\begin{array}{l}0.055 \\
(1.3)\end{array}$ \\
\hline Year 1997 (Dummy) & $\begin{array}{l}-0.076 \\
(-1.4)\end{array}$ & $\begin{array}{l}0.127 \\
(2.8)\end{array}$ & $\begin{array}{c}0.113 \\
(2.6)\end{array}$ \\
\hline $\mathrm{R}^{2}$ & 0.266 & 0.287 & 0.263 \\
\hline
\end{tabular}

Note: t-statistics in parentheses. Sample size is 3,351 for all regressions. Total compensation defined as the sum of salaries, bonuses, benefits, share options (valued on date of grant using the Black-Scholes formula), LTIP-related stock grants (valued at $80 \%$ of face value for performance-contingent awards), and other compensation. Risk-adjusted compensation is computed assuming constant relative risk aversion and assuming that CEO has "safe wealth" equal to the greater of $\$ 5$ million or four times cash compensation. All monetary variables in 1988-constant dollars. 
Table 3

Cost, Value, and Incentives from Executive Options with and without Early Exercise

\begin{tabular}{|c|c|c|c|c|c|c|c|c|c|}
\hline \multirow[b]{2}{*}{$\begin{array}{c}\text { Risk } \\
\text { Aversion }\end{array}$} & \multirow{2}{*}{$\begin{array}{c}\% \text { of } \\
\text { Wealth } \\
\text { in Stock }\end{array}$} & \multicolumn{4}{|c|}{ Options Exercisable at Expiration } & \multicolumn{4}{|c|}{ Options Exercisable at Grant } \\
\hline & & $\begin{array}{c}\text { Company } \\
\text { Cost }\end{array}$ & $\begin{array}{l}\text { Executive } \\
\text { Value }\end{array}$ & $\frac{\text { Value }}{\text { Cost }}$ & $\begin{array}{l}\text { Incentives } \\
\partial \mathrm{V} \partial / \mathrm{P}\end{array}$ & $\begin{array}{c}\text { Company } \\
\text { Cost }\end{array}$ & $\begin{array}{l}\text { Executive } \\
\text { Value }\end{array}$ & $\frac{\text { Value }}{\text { Cost }}$ & $\begin{array}{c}\text { Incentives } \\
\partial \mathrm{V} \partial / \mathrm{P}\end{array}$ \\
\hline 2 & $50 \%$ & $\$ 16.55$ & $\$ 10.51$ & $63.5 \%$ & $\$ 0.45$ & $\$ 14.76$ & $\$ 12.40$ & $84.0 \%$ & $\$ 0.61$ \\
\hline 2 & $67 \%$ & $\$ 16.55$ & $\$ 7.41$ & $44.8 \%$ & $\$ 0.35$ & $\$ 13.60$ & $\$ 9.96$ & $73.2 \%$ & $\$ 0.56$ \\
\hline 3 & $50 \%$ & $\$ 16.55$ & $\$ 6.07$ & $36.7 \%$ & $\$ 0.26$ & $\$ 13.06$ & $\$ 9.42$ & $72.1 \%$ & $\$ 0.53$ \\
\hline 3 & $67 \%$ & $\$ 16.55$ & $\$ 3.49$ & $21.1 \%$ & $\$ 0.17$ & $\$ 11.57$ & $\$ 7.33$ & $63.4 \%$ & $\$ 0.49$ \\
\hline
\end{tabular}

Note: The data depict the per-share costs, value, and incentives from a grant of 5,000 ten-year stock options with an exercise price of $\$ 30$ (the market price on the date of grant). The cost is estimated as the binomial valuation of an American option (under riskneutral pricing), where the exercise decision is determined not by the investor but rather by the threshold prices in Figure 7 . The value is estimated as the grant-date cash award that yields the same expected utility as receiving an option, and incentives are measured as the derivative of this value with respect to an incremental change in the stock price. The executive is assumed to have initial wealth of $\$ 5$ million, split between riskless cash and company stock. 
Table 4

\section{Likelihood of Exercising on Vesting Date}

\begin{tabular}{cccccc}
\hline \hline \multirow{2}{*}{$\begin{array}{c}\text { Risk } \\
\text { Aversion }\end{array}$} & $\begin{array}{c}\text { Diversification } \\
\text { (\% of Wealth } \\
\text { in stock })\end{array}$ & & \begin{tabular}{c} 
Vesting at \\
\cline { 5 - 6 } \cline { 5 - 5 } 2 Years
\end{tabular} & $\begin{array}{c}\text { Vesting at } \\
\text { 3 Years }\end{array}$ & $\begin{array}{c}\text { Vesting at } \\
\text { 4 Years }\end{array}$ \\
\hline 2 & $50 \%$ & & $1.4 \%$ & $5.8 \%$ & $10.0 \%$ \\
2 & $67 \%$ & & $5.9 \%$ & $12.9 \%$ & $19.8 \%$ \\
3 & $50 \%$ & & $5.9 \%$ & $16.7 \%$ & $23.7 \%$ \\
3 & $67 \%$ & & $17.0 \%$ & $26.3 \%$ & $33.3 \%$ \\
\hline
\end{tabular}

Note: The executive, with initial wealth of $\$ 5$ million, split between riskless cash and company stock, is assumed to receive 5,000 ten-year stock options with an exercise price of $\$ 30$ (the market price on the date of grant). Exercise probabilities are based on a simulation with 100,000 sample price paths (through the tree) for each risk/diversification/vesting group. The likelihood of exercising at vesting date is calculated as the percentage of price paths (out of 100,000) that exceed the threshold price at the executive's first opportunity to exercise. 


\section{Figure 1}

\section{Executive Value Lines: Option Values for Undiversified Executives}

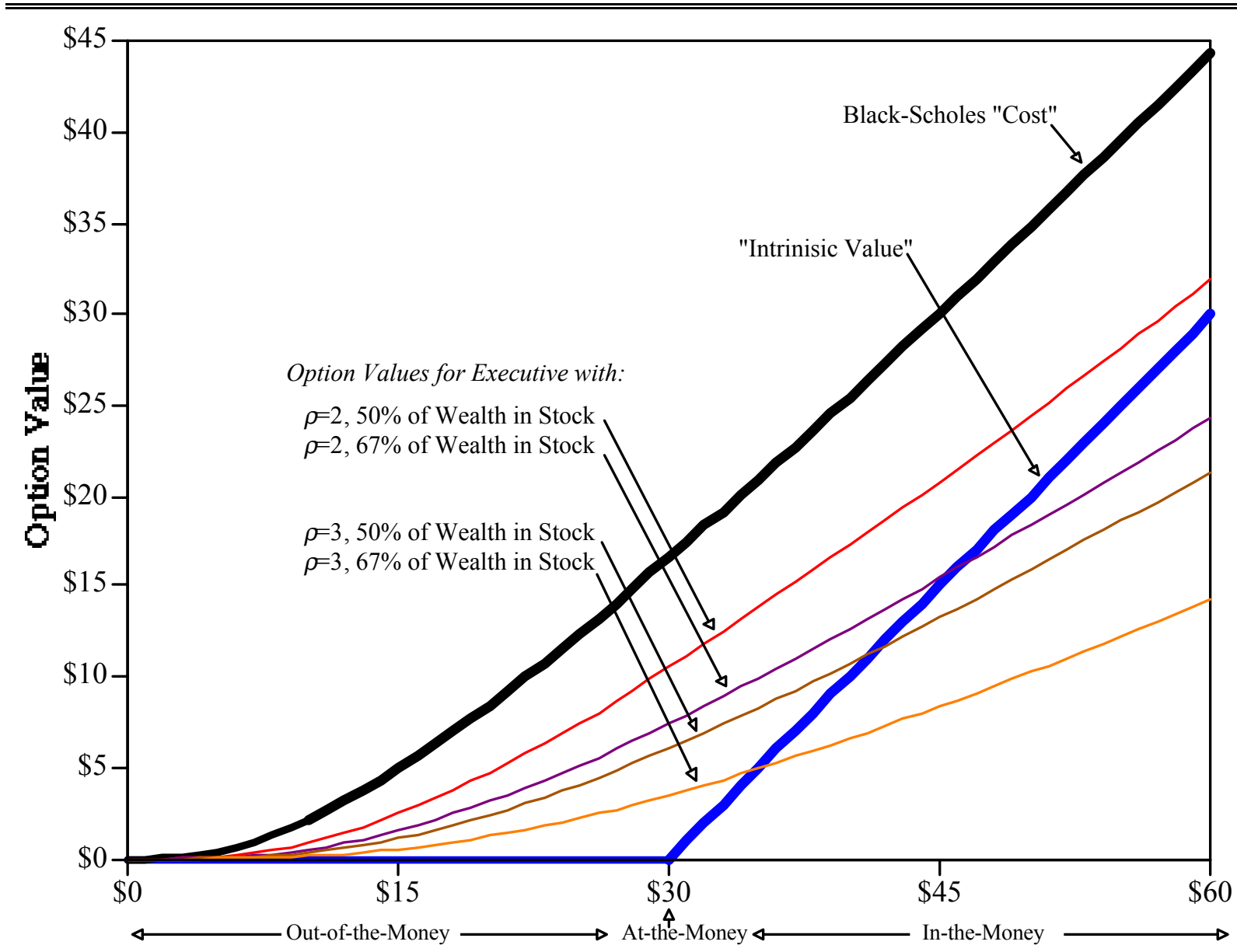

\section{Stock Price}

Note: Executive values for ten-year options with an exercise price of $\$ 30$ are estimated using the "certainty equivalence" approach, and are defined as the amount of riskless cash compensation the executive would exchange for the option. Certainty equivalents are estimated numerically assuming that the executive has constant relative risk aversion, $\rho=2$ or $\rho=3$, and assuming (using the Capital Asset Pricing Model, CAPM) that the distribution of stock prices in T=10 years is lognormal with volatility $\sigma=.30$ and expected value $\left(r_{f}+\beta\left(r_{m}-r_{f}\right)-\sigma^{2} / 2\right) T$, where $\beta=1$ is the firm's systematic risk, $r_{f}=6 \%$ is the risk-free rate, and $r_{m}-r_{f}=6.5 \%$ is the equity premium. 
Figure 2

Executive Indifference Curves: Amount of Stock-Based Pay Required to Offset $\mathbf{\$ 3 0 0 , 0 0 0}$ in Cash Compensation

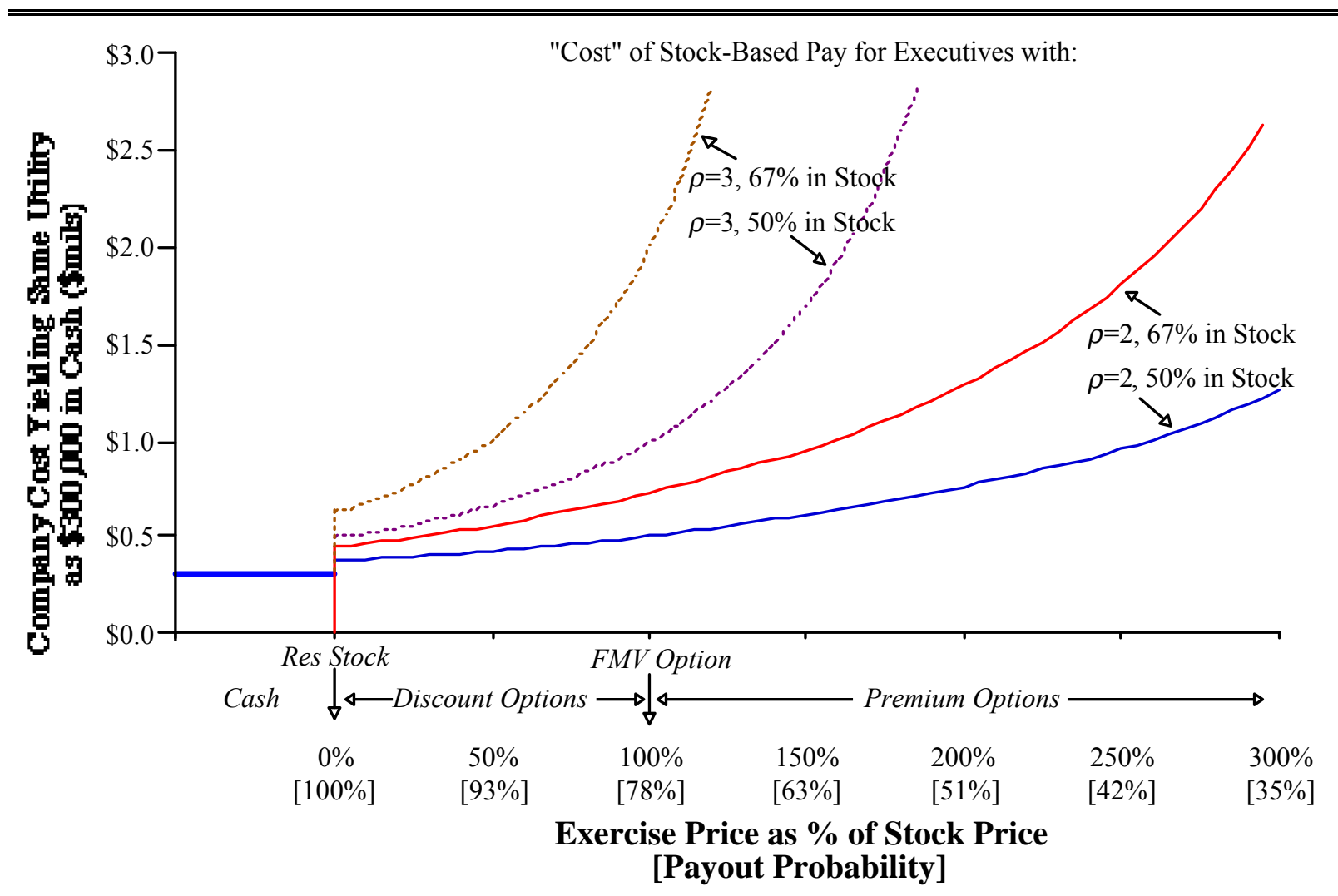

Note: Executive values are estimated numerically assuming that the executive has constant relative risk aversion, $\rho=2$ or $\rho=3$, and assuming (using the Capital Asset Pricing Model, CAPM) that the distribution of stock prices in T=10 years is lognormal with volatility $\sigma=.30$ and expected value $\left(r_{f}+\beta\left(r_{m}-r_{f}\right)-\sigma^{2} / 2\right) T$, where $\beta=1$ is the firm's systematic risk, $r_{f}=6 \%$ is the risk-free rate, and $r_{m}-r_{f}=6.5 \%$ is the equity premium 
Figure 3

CEO Pay and Risk-Adjusted Pay in S\&P 500 Industrials, 1992-1998

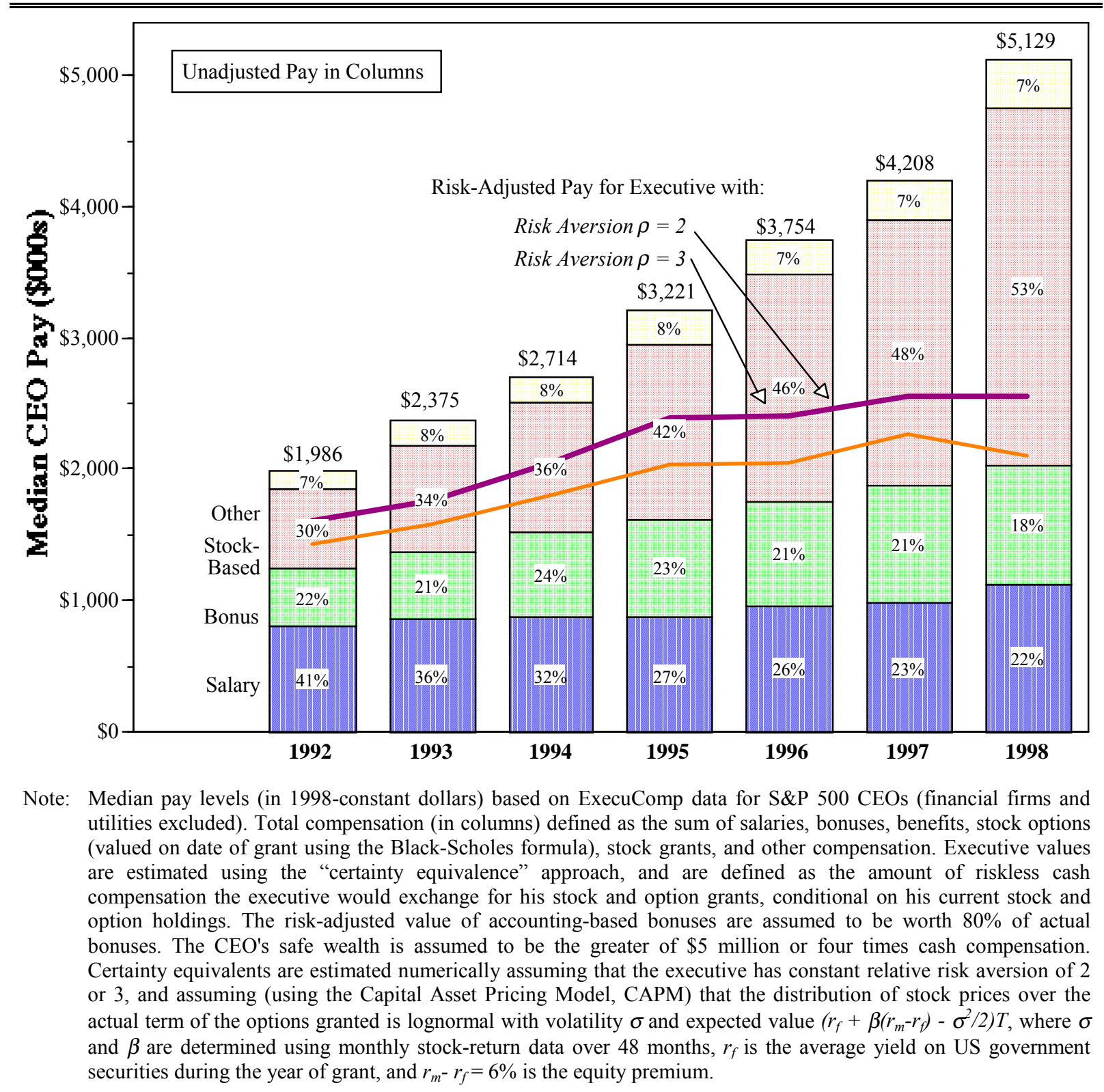




\section{Figure 4}

Incentives (per share) from 5,000 Options Granted to Undiversified Executives

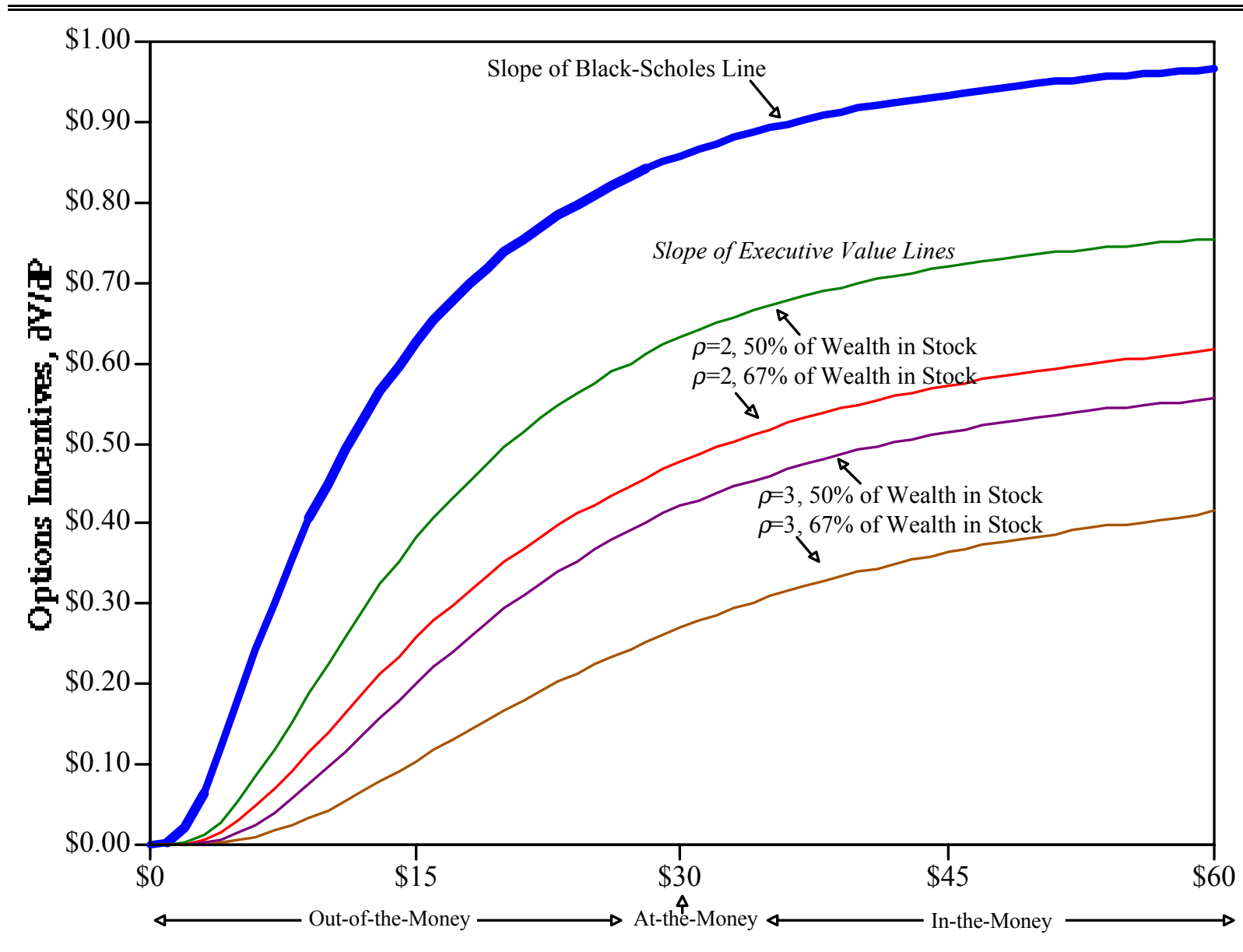

Stock Price

Note: The figure shows the "slopes" of the Black-Scholes and executive valuations in Figure 1, which in turn depict the per-share cost and value of a grant of one ten-year option with an exercise price of $\$ 30$. We define "incentives" as the change in the certainty-equivalent option value for each $\$ 1$ change in the stock price. 
Figure 5

Incentives from \$300,000 “worth” of Options Granted to Undiversified Executives

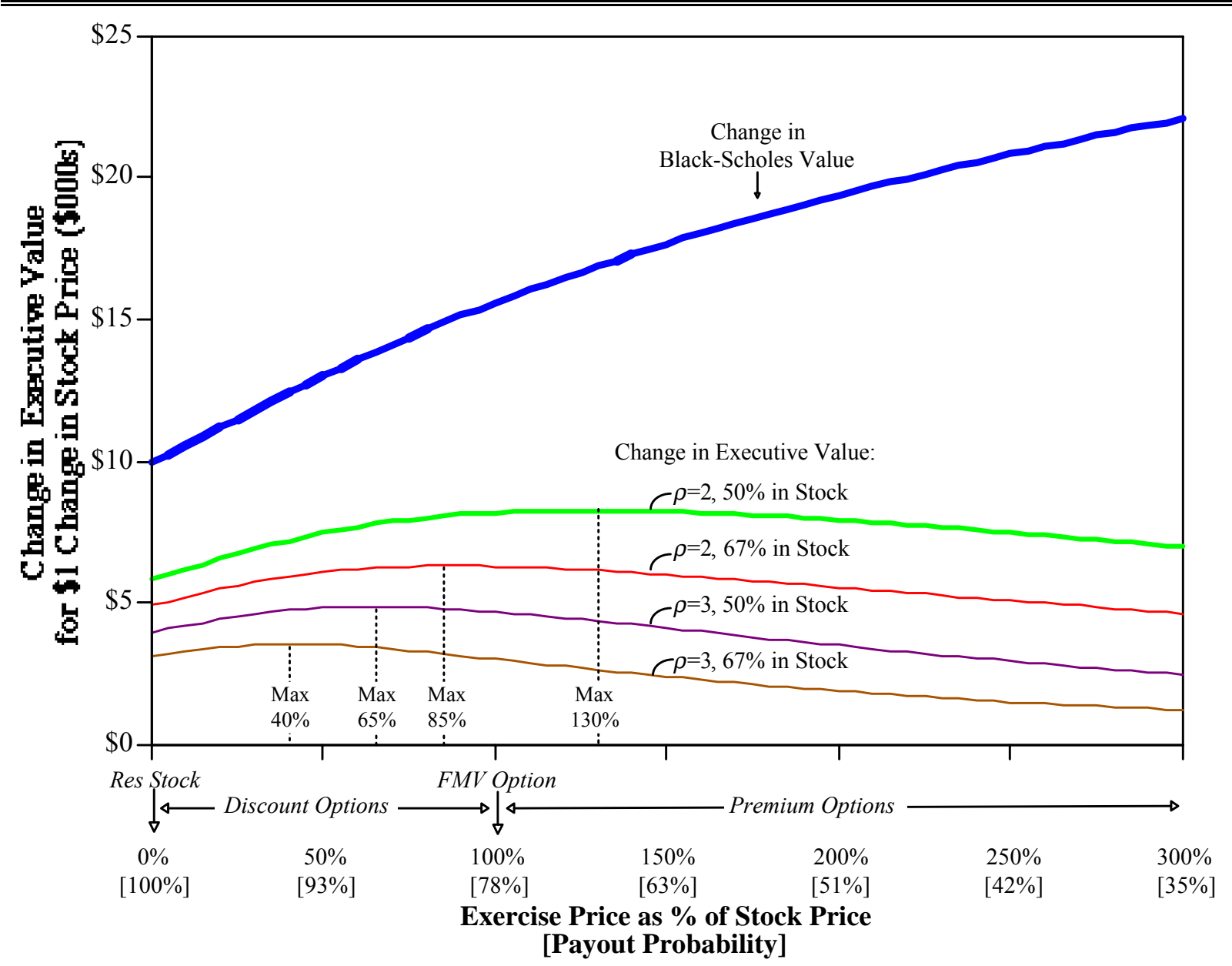

Note: The figure assumes that executives with $\$ 5$ million in initial wealth are granted stock options with a Black-Scholes value of $\$ 300,000$; the number of options granted naturally increases as the exercise price increases. We define "incentives" as the change in the certainty-equivalent option value for each $\$ 1$ change in the stock price. 
Figure 6

Incentives from Options with a "Net Cost" of $\$ 100,000$ Granted to Undiversified Executives

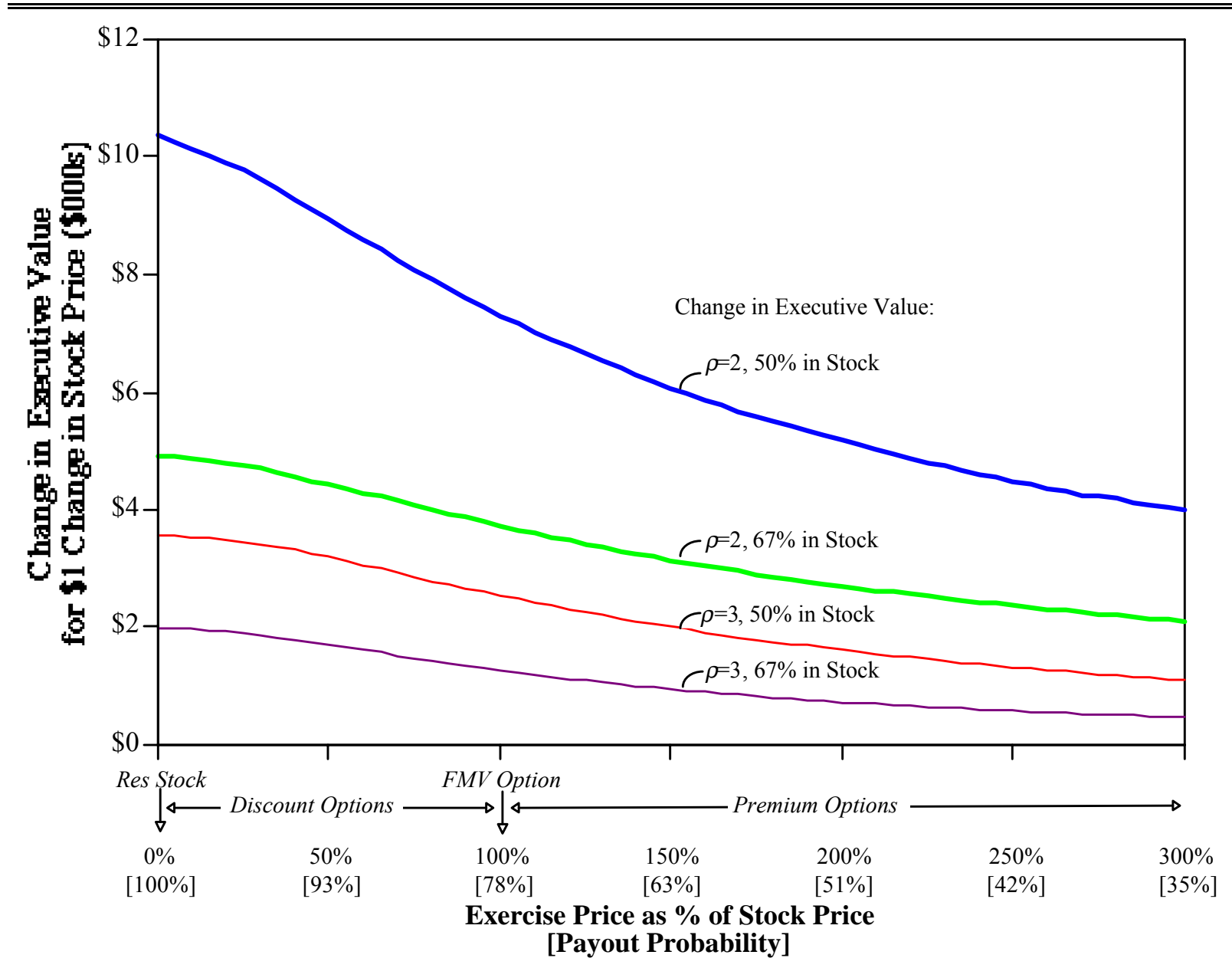

Note: Net cost is defined as the Black-Scholes value less the Executive Value. The figure assumes that executives with $\$ 5$ million in initial wealth are granted stock options with a net cost of $\$ 100,000$; the number of options granted naturally increases as the exercise price increases. We define "incentives" as the change in the certainty-equivalent option value for each $\$ 1$ change in the stock price. 
Figure 7

“Threshold Prices” for Early Exercise Decisions on Immediately Exercisable Options

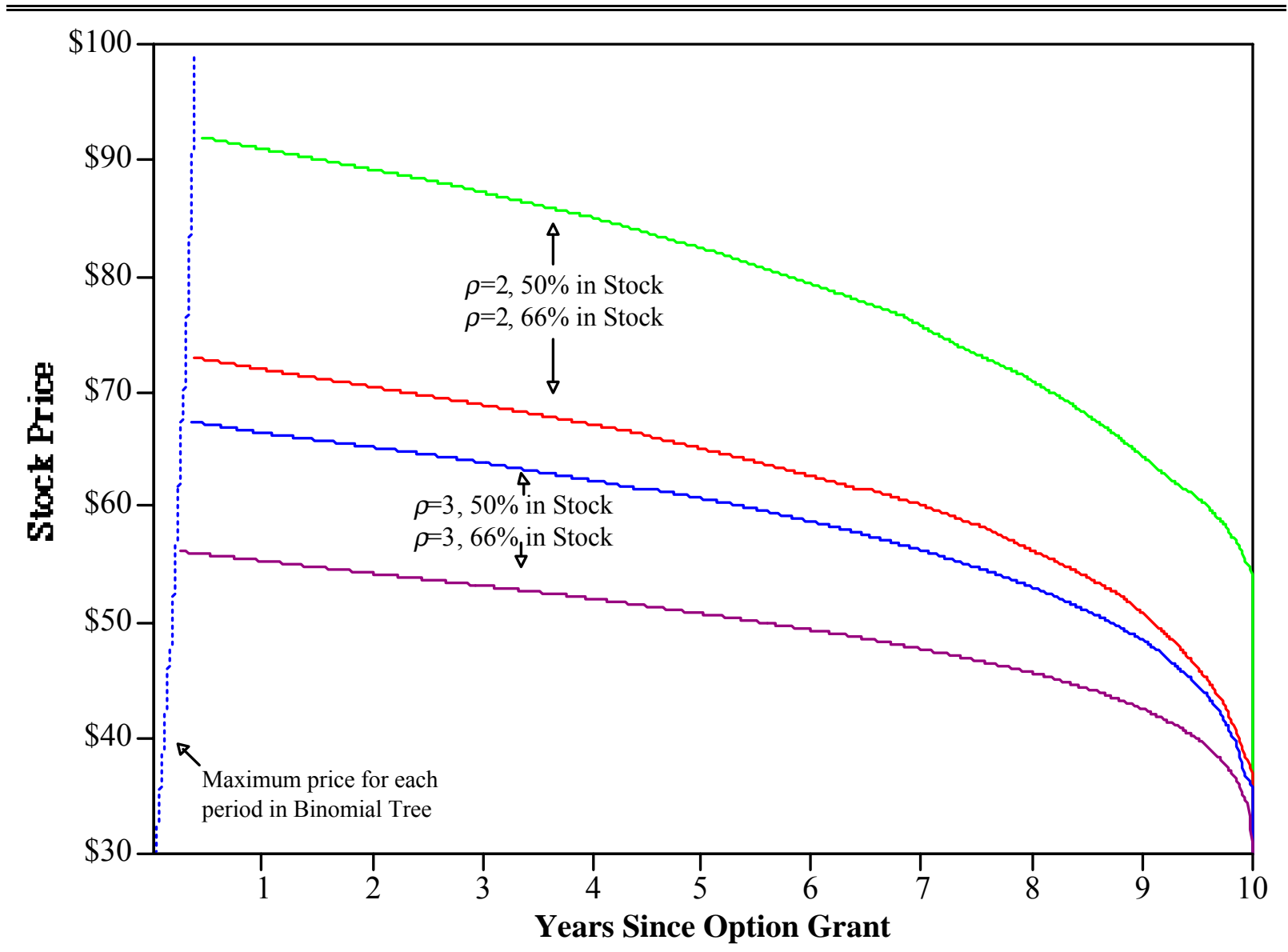

Note: The threshold price is the stock price where the executive is just indifferent between exercising early or holding the option for another period. The figure assumes that executives with $\$ 5$ million in initial wealth are granted 5,000 immediately exercisable stock options. At exactly $\mathrm{T}=10$, the threshold price falls to the exercise price of $\$ 30$. 
Figure 8

Cumulative Exercise Probabilities for Immediately Exercisable Options

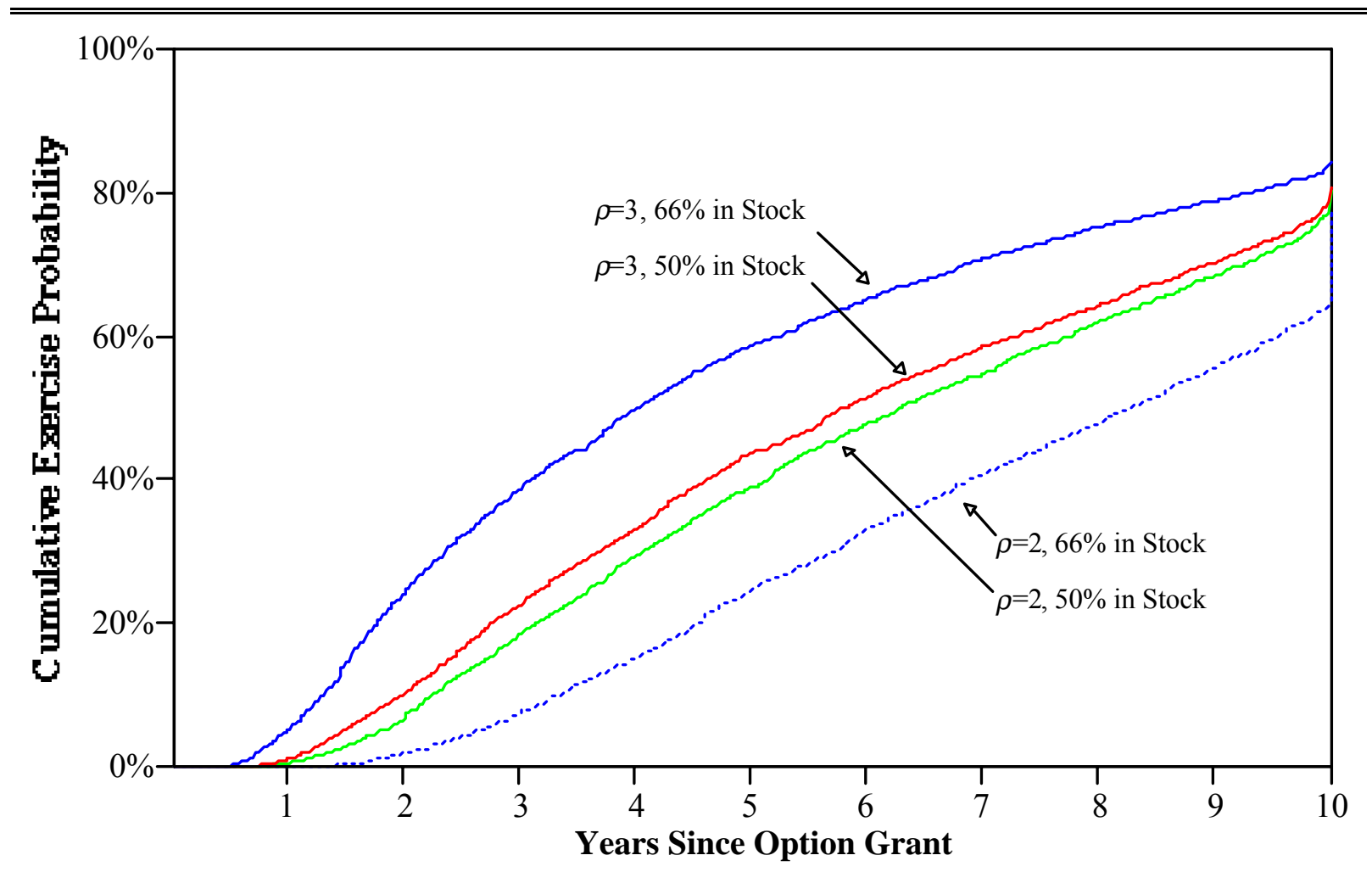

Note: The figure shows the cumulative probability of exercise for an executive with $\$ 5$ million in initial wealth and an option grant of 5,000 options. All of our other assumptions are maintained from our earlier analysis. 


\section{Figure 9}

The Ratio of the Executive Value to the Company's Cost, by Vesting Date

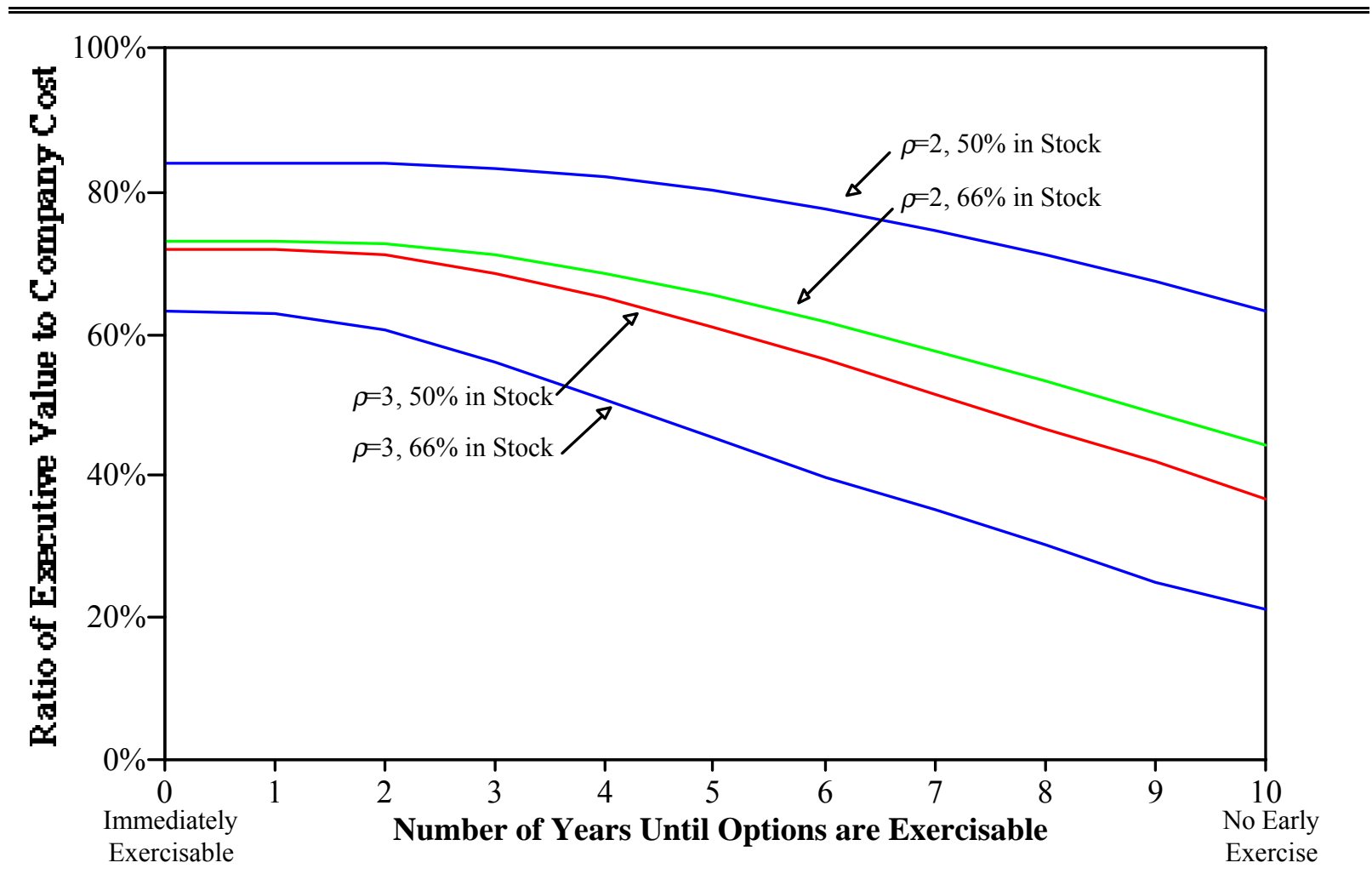

Note: The figure shows the value:cost ratios for various vesting lengths for an executive with $\$ 5$ million in initial wealth and an option grant of 5,000 options. All of our other assumptions are maintained from our earlier analysis. 